\title{
Dutch Tobacco Control Policy from the 1950s to the Present
}

Tobacco control policy is a long step from the neat theoretical path of identifying a problem, selecting the most effective strategy to tackle it, and then just implementing it. This chapter describes the many steps that were taken by the Dutch government to shape tobacco control policy. The description covers more than half a century and stays close to the timeline of events. The reader will learn how the government chose to combat smoking from the early years when it first became clear that smoking is not an innocent pleasure. At first the government was hesitant to react, but in the 1970s it became more active, culminating in a Tobacco Memorandum with far-reaching policy proposals, many of which were killed or toned down over subsequent years. The fight over tobacco policy then concentrated on two major national pieces of legislation: the 1988 Tobacco Act and its 2002 revision. These were not definitive laws but "framework" laws-meaning that they offered the basis for more specific decisions to be taken by the Council of Ministers (so-called orders-in-council) or by a minister (Ministerial Regulations) at a later stage. This opened up long periods of bargaining between interest groups, politicians, and the government about interpretations during the implementation phase.

M. C. Willemsen, Tobacco Control Policy in the Netherlands, Palgrave Studies in Public Health Policy Research, https://doi.org/10.1007/978-3-319-72368-6_2 


\section{Emerging Health Concerns (1950-1970)}

Shortly after the Second World War, W.F. Wassink, a physician at the Antoni van Leeuwenhoek hospital in Amsterdam, published the results of a case-control study comparing the smoking habits of 137 male lung cancer patients with a control group of 100 "normal" men. He concluded that tobacco had to be the cause of the disease (Wassink, 1948). Two years later, a landmark study was published by British epidemiologists Richard Doll and Austin Bradford Hill (Doll \& Hill, 1950). In the same year, a group of American epidemiologists concluded that the main cause of the rise in lung cancer death was smoking (Wynder \& Graham, 1950). The international media quickly picked up the story. In 1952 the popular US-based Reader's Digest published an article entitled "Cancer by the Carton." This was the first mainstream publication that bluntly stated that smoking causes cancer, and blamed the high cancer rates on the tobacco industry's relentless promotion of tobacco. The effect was tremendous. Cigarette sales declined for the first time in over two decades in the United States.

In these years, the Netherlands was still a smokers' society, and in 1958 $90 \%$ of men and $38 \%$ of women smoked (Gadourek, 1963, p. 66). Although Readers Digest was not distributed in the Netherlands at the time, the concern about smoking was felt. Alarming messages from the international studies that smoking can cause lung disease were summarised in a report from the Dutch Health Council (Wester, 1957) and attracted some attention in the Netherlands.

In March 1962 the British Royal College of Physicians of London published a landmark report that summarised the medical evidence and urged the UK government to take action (Royal College of Physicians, 1962a). It appeared in the same year in a Dutch translation (Royal College of Physicians, 1962b), and this attracted abundant media attention. From that moment, smokers' health was part of general public attention and tobacco use lost much of its innocence. In the summer of 1963, reports from the Dutch Central Bureau of Statistics about an alarming increase in lung cancer deaths among Dutch men were discussed extensively by the media and on national television, and this was a good reason for Senator Kranenburg (Christian Historical Union [CHU], a small protestant party) to ask the government whether it accepted that smoking causes lung cancer. ${ }^{1} \mathrm{He}$ also wanted to know what the government was going to do about it. Although the state secretary for health acknowledged that smok- 
ing was the leading cause of lung cancer, the government's response was restricted to education in schools, although it took the imposition of measures to reduce smoking under consideration. The Dutch Cancer Society received subsidies from the government in the order of a few hundred thousand guilders per year to execute these education campaigns. The Dutch government's minimal response was similar to the hesitant response of the UK government at the time (Berridge \& Loughlin, 2005).

The next year, a report from the US Department of Health, Education, and Welfare (1964) (Smoking and Health), based on a review of over 7000 scientific articles, concluded unequivocally that there was a causative link between smoking and a 10 - to 20 -fold increase in the occurrence of lung cancer. This report had a lasting worldwide effect on how smoking was perceived. The year 1964 can be regarded as the year when serious concerns about smoking stirred the Dutch nation and health organisations like the Dutch Cancer Society got actively involved with tobacco control.

In 1965 tobacco manufacturers united in an effort to prevent government regulation of advertising, and reached a "gentlemen's agreement" in which they promised to stop marketing that suggested some brands were "better for health" than others (Tobacco Manufacturers' Association, 1971). They also promised to abstain from television commercials. Since tobacco commercials were not broadcast on Dutch television, this offer was not particularly impressive. Similar codes of conduct surfaced in Germany, Belgium, and Luxembourg (Pauw, 1971). ${ }^{2}$ The UK-based manufacturers had agreed in 1962 to implement a code of advertising practice that would detract some of the glamour from cigarette advertisements (ASH, 2013). This strategy of self-regulation was successful in preventing governmental regulation of tobacco advertising for many years. The self-imposed restrictions in the Netherlands had no formal or legislative status, but were subject to scrutiny by the Stichting Reclame Code (Advertising Code Foundation) (SRC), an organisation founded in 1963 by the advertising sector to handle citizens' complaints about advertisements. ${ }^{3}$

In 1968 the US Department of State inquired through its embassies about tobacco control activities in 22 countries (National Clearinghouse for Smoking and Health, 1969; US Public Health Service, 1970). Few countries had taken action. Twelve had not started even rudimentary education in schools, and many were waiting for advice from their national health councils. However, some were already taking the first regulatory steps. Some had banned advertising on television (Italy, 
Norway, Sweden), some had banned the sale of tobacco to minors (Austria, Norway), and some had initiated communication campaigns that went beyond youth education (Canada, the United Kingdom, Italy). Dutch tobacco control policy was restricted to providing subsidies for youth education, while the industry exhibited self-restraint regarding tobacco advertisements. In sum, at the end of the 1960s the Netherlands had no tobacco control legislation despite growing health concerns. The only action taken by the government was to provide a small yearly subsidy to the Cancer Society's youth education school programmes.

\section{Ambitious Policy Intentions (1970-1977)}

In 1970 Hans van den Doel, a Labour Party member of the lower house of the Dutch Parliament, asked whether the government was aware that US President Nixon had signed an intention to ban tobacco advertisement on radio and television and to put health warnings on cigarette packs. ${ }^{4}$ Van den Doel wanted to know if the Dutch government intended to follow the American example. The government responded by setting up a working group with representatives from five governmental departments (the Ministries of Health, Social Work, Justice, Economic Affairs, and Finance), commissioned to examine the possibility of restricting tobacco advertisements. ${ }^{5}$ This working group was called the Meulblok Committee after its Chairman J. Meulblok, head of the Public Health Department of the Ministry of Health.

Between 1971 and 1972 Dutch tobacco manufacturing organisations had several meetings with the Meulblok Committee about tobacco advertising. Meulblok actively sought input from the industry and felt that it was important that the committee and the industry were on the same wavelength (Interdepartementale Commissie Tabaksreclame, 1972a). The Committee's starting point was that it wanted "if possible, to prevent the necessity of interventions by the government" (Interdepartementale Commissie Tabaksreclame, 1972b). It struggled especially with the legal aspects of a ban on tobacco advertising, being under constant pressure from the tobacco industry to refrain from advising about advertising regulation. Meulblok thus wanted to first explore the option of self-regulation, because the committee expected that an advertising ban would be difficult to reconcile with constitutional rights 
of freedom of press and freedom of speech (Interdepartementale Commissie Tabaksreclame, 1972a). Meulblok wondered if this might show "where a small country such as the Netherlands can be great and be an example to other countries."

It was not only the lower house of the Dutch Parliament that was concerned about the smoking issue. In 1971 Upper House Senator Sidney Van den Bergh of the Volkspartij voor Vrijheid en Democratie (People's Party for Freedom and Democracy) (VVD), the conservativeliberal political party, read the second report from the UK Royal College of Physicians, "Smoking and Health: Now," which concluded that smokers were twice as likely to die by middle age than non-smokers and recommended health warnings on cigarette packs, advertising restrictions, and tax increases (Royal College of Physicians, 1971). When Van den Bergh asked the Dutch state secretary for health whether he was considering similar steps. ${ }^{6}$ The state secretary responded by asking the Health Council for advice on how the government should inform the public about the risks of smoking. It is interesting to compare this reserved Dutch response to what was happening at the time in the United Kingdom. The English Health Education Council initiated a series of hard-hitting awareness campaigns in the beginning of the 1970s that shook up the public. Advertisements had texts such as, "The tar and discharge that collect in the lungs of the average smoker," "You can't scrub your lungs clean," and "Why learn the truth about lung cancer the hard way?" (Berridge \& Loughlin, 2005). One advertisement showed smokers crossing London's Waterloo Bridge interspersed with images of lemmings throwing themselves off a cliff. A 1973-1974 campaign showed a naked pregnant smoking woman featuring the text, "Is it fair to force your baby to smoke cigarettes?" In 1978 the English Health Education Council attacked the industry's claim that safer cigarettes would be the solution, through an advertisement that had the line, "Switching to a substitute cigarette is like jumping from the 36th rather than the 39th floor of a building" (Berridge \& Loughlin, 2005). Such campaigns paved the way for a more assertive and proactive governmental response to the smoking problem in the United Kingdom. The Dutch government did not take similar actions.

In 1975 the Health Council's report Measures to reduce smoking was published. A commission of 12 experts had worked on it for almost two and a half years, convening 16 times. Surprisingly, their conclusions were 
quite revolutionary at the time, and threatening to those with a vested interest in the tobacco sector. It stated as a starting point that "public health interests must prevail above economic interests" (Beernink \& Plokker, 1975, p. 7). The report contained a comprehensive and integrated set of policy proposals.

The report concluded that "considering the large influence of smoking on the people's health, it is unjust and impossible for the government to look the other way much longer" (Beernink \& Plokker, 1975). Interestingly, the report noted that full freedom of choice did not exist with respect to smoking because smokers had become pharmacologically and psychologically dependent on tobacco use after exposure to so much tobacco advertising. Tobacco control had to be "aimed primarily at the creation of a psycho-social climate in which smoking is negatively influenced and at stimulating a new attitude regarding smoking." The government was advised to communicate unequivocally to the public that smoking poses a serious danger to the health of smokers and non-smokers.

Measures to reduce smoking proposed a comprehensive programme of educational and regulative measures-and a 15-year action plan to tackle the smoking epidemic. The government was advised to consider a full tobacco advertising ban, restrictions on the availability of tobacco, removal of tobacco vending machines, increases in tobacco taxes to fund antitobacco advertising campaigns, and the banning of smoking in public places (see Box 2.1 for a more complete account of the commission's recommendations). Tobacco control policy was to be supported by financial means that were in fair proportion to the advertising budgets that tobacco companies had at their disposal and to the revenues that the government received from tobacco taxes.

Measures to reduce smoking could have been the starting point for the development of a comprehensive national tobacco control strategy or plan, but it did not translate into policy. Looking back at the report through modern eyes, it had all the necessary ingredients to propel the Dutch to leadership in the field. However, hardly any of the ideas was taken up. Some of the measures took many decades to materialise, others, such as a ban on vending machines and earmarked tobacco tax revenues, are still not realised. The progressive cabinet of the time (led by Labour Party leader Joop den Uyl) was not followed by a cabinet that put the policy intentions into action. 


\section{Box 2.1 Proposals in the 1975 Health Council report Measures to} reduce smoking

- A ban on tobacco advertising

- Health warnings on cigarette packs

- Restrictions on smoking in public places, in combination with an educational campaign to explain the measure

- Smoking restrictions for specific occupations, such as doctors and teachers

- A smoking ban on public transport

- Restrictions on smoking in television shows and other programmes

- Restrictions on the number of points of sale of tobacco

- Removal of tobacco vending machines

- A ban on the sale of tobacco to minors (under 16 years of age). This measure was to be considered if the removal of vending machines was not effective enough

- Increasing tobacco taxes in tandem with neighbouring countries, the extra revenue to be allocated to anti-tobacco campaigns

- Consideration of a ban on the duty-free sale of tobacco products

- Mass media campaigns to stimulate interpersonal communication about the dangers of smoking, and to encourage the formation of group norms incompatible with smoking

- Health education programmes in schools, worksites and civil society organisations

- Motivation and training of health educators, doctors, and teachers to enable them to motivate and support patients, clients, and pupils not to smoke

- Developing effective behavioural counselling for smokers who wish to quit

- Foundation of a National Institute for the Reduction of Smoking, responsible for providing general information to the public, and for the coordination of education, campaigns, smoking cessation support, and research

- Development of a long-term scientific research program to include systematic monitoring of the smoking habits of the population and evaluation of the effectiveness of all current and future tobacco control measures, plus research into the psychological and sociological determinants of smoking, the best ways of supporting smokers to quit smoking, and the impact of smoking on health 
One recommendation from the Health Council's report was taken up, though. This was the creation of a national institute for tobacco control, leading to the foundation of Stichting Volksgezondheid en Roken (Dutch Smoking or Health Foundation) (STIVORO). Since the core of the government's approach to tackling the smoking problem was health education, the new institute's tasks were to educate the public about smoking and to monitor national smoking habits through yearly surveys (see Chap. 9 for an account of STIVORO's role in tobacco control).

Soon after the publication of the Health Council's report, the Meulblok Committee presented its report to the cabinet, which sent it to the parliament in 1976. The Meulblok Committee stayed close to the Health Council's recommendations (Meulblok, 1975). It adopted the council's starting point: that the interests of public health must prevail above other interests. Meulblok pointed out that any negative impact on employment or tax revenues could not outweigh the necessity of protecting the public's health. Another starting point was that priority must be given to the protection of youth, and that this must not be restricted to education.

For the government, the Meulblok report was the starting point of a long process that eventually resulted in a "Tobacco Act." A particularly important recommendation from Meulblok was to start drafting a law to ban tobacco advertising. The committee's argument was that "advertising constantly confirms and reinforces the usual [positive] attitude in our society regarding smoking" (p. 28). The committee left open the possibility of a gradual approach, involving a series of restrictions, in the case that a full advertising ban was politically undesirable or unfeasible, but dismissed the idea of self-regulation by the industry. Frequent consultations with industry representatives had not convinced the committee to refrain from legislation. The industrial lobby had broken ranks and could not offer an acceptable, mutually agreed-upon alternative. Niemeyer, a local producer of cigarettes, no longer respected the gentlemen's agreement between manufacturers, part of which was that advertisements must not give the impression that one type or brand of tobacco was less harmful than others. Niemeyer, a market leader in brands of cigarettes with distinct harm reduction appeal, wanted to promote its brands Roxy Dual and Kelly Halvaret as low in nicotine and tar and relatively safe for consumers, and concluded that this was more profitable for them than adhering to the industry's mutual but non-binding caveats.

Since the industry was not able to present a convincing alternative, the Meulblok Committee advised the cabinet to start the process of drafting a 
Tobacco Act that included advertising restrictions (Meulblok, 1975). The recommendations were threatening to the tobacco industry-which spent no less than 35 million guilders (about $€ 40$ million in current money) on tobacco advertising in 1977 (Algemene Rekenkamer, 1982).

The Meulblok Report was produced during the Den Uyl cabinet (1973-1977), the most progressive cabinet that the Netherlands has ever had. It comprised Christian Democrats and parties left of the political centre. Prime Minister Den Uyl (Labour Party) was credited for trying to free politics from corporatism. This was an era when the ideal of a better world dominated the political discourse, and many believed in the idea of a just and modifiable society (maakbare samenleving). In January 1977, just two months before Den Uyl's cabinet resigned, State Secretary for Health Jo Hendriks sent a letter to the parliament outlining the cabinet's strategy to combat smoking. ${ }^{7}$ This Tobacco Memorandum (Rookmemorandum) put forth the recommendations from the Measures to reduce smoking report from the Health Council and ideas from the Meulblok Report that were felt would be the most feasible to implement. ${ }^{8}$ Hendriks decided upon a "not too hasty approach" by not implementing all of the measures proposed by the Health Council at once, but by opting to do it gradually. ${ }^{9}$ Health educational efforts had to be intensified, and accompanied by the three measures that the government felt it could implement on relatively short notice: bans on smoking in public venues, governmental buildings, and areas such as waiting rooms; labelling tobacco products (with health warnings and tar and nicotine yields); and a ban on tobacco advertising. Other measures were considered for the longer term. ${ }^{10}$ The cabinet noted that smoking restrictions would help build a social climate in which non-smoking was the norm and that it might be a good idea, for each subsequent longterm measure, to estimate the extent to which the measure restricted the freedom of the individual. It was decided that a further analysis of the proposals was needed, including legal and political feasibility. A new committee was set up in July 1977 to do this. This Interdepartementale Commissie Beperking Tabaksgebruik (Interdepartmental Committee for Reducing Tobacco Use) (ICBT) consisted of delegates from six state departments, but mostly from the health and trade ministries (both had four seats at the table, but the Ministry of Health delivered the chair, vice-chair, and secretary). The committee's task was to formulate concrete proposals for regulative measures-other than education-to reduce tobacco use. ${ }^{11}$ 
Partly due to a change of government, it was almost two years (March 1979) before the committee was officially installed and started work. In the meantime, advice from the Meulblok Committee to introduce health warnings was followed through in a proposal for a law that was attached to the Food and Product Safety Act in 1981, ordering that from January 1982 onwards tobacco products had to carry the health warning, "Smoking threatens health. The Minister of Public Health and the Environment." Mandatory information about tar and nicotine content was also included. This was less confronting than the advice from Meulblok to use the text "Smoking damages yourself and others."

\section{The Ministry of Economic Affairs Steps on the Brake} (1977-1991)

In December 1977, the first cabinet under Christian Democratic leader Dries Van Agt came to power and changed the political landscape profoundly. This centre-right government was "fairly tolerant towards smoking," according to an internal industry memo (Colby, 1979). Philip Morris' analysis was that "the new government is favouring industry more than its predecessor. However, more legislation will probably be enacted, but in such a way as not to interfere with the economic situation; the Ministry of Finance and Economic Affairs carries considerable weight in Holland" (Unknown (Philip Morris), 1979). The government's position on tobacco from the first Van Agt cabinet until the third Lubbers cabinet (mid-1990s) can be characterised by the mantra "tobacco is an individual's own responsibility." Governments in these years were not happy with the Meulblok and Health Council reports and effectively bogged their recommendations in bureaucratic procedures.

One of the first things the new cabinet did was to tone down the ambitious tobacco control policy intentions of the previous cabinet. In a letter to Parliament, the new state secretary for economic affairs wrote that, "given the interests of businesses that are at stake here, I will make sure that tobacco control policy with respect to the supply side will be developed in a careful, gradual manner, in connection with the policy with respect to the demand-side." 12 Everything having to do with legally binding restrictions, including tobacco advertising and regulation of the sale of tobacco, was handled by the Ministry of Economic Affairs. The Ministry of Health controlled the demand-side. This division of tasks ensured that effective tobacco policy measures could not be made without the consent 
of the powerful Minister of Economic Affairs, who could step on the brake whenever the Ministry of Health moved too fast.

In March 1979, the ICBT committee began to work on its policy proposal report. The cabinet did not put much pressure on the commission, which was allowed to take its time. The new State Secretary for Health, Els Veder-Smit of the conservative-liberal VVD, regarded self-regulation by the industry as the best alternative to an advertising ban. ${ }^{13}$ She believed that personal freedom and the responsibility of individuals for their own health were important aspects for the ICBT to keep in mind when considering appropriate measures. While the ICBT was working on its report, the tobacco industry presented a list of self-imposed advertising restrictions. This included old promises such as refraining from advertisements directed at youth and from making health claims, and ending the promotion of tobacco products through television and radio. ${ }^{14}$ In 1979 the state secretary explained that "from our contacts with the tobacco manufacturing industry it is clear to us that they are prepared to ban health appeals from their advertising messages." 15 She trusted self-restraint by the industry, as long as this was supported by all manufacturers and backed by sanctions. The ICBT was requested to take the industry's proposals into account.

Parliament was more critical of the industry's self-regulative proposals. The Christen-Democratisch Appèl (Christian Democratic Party) (CDA) claimed that the industry had failed, and tabled a motion to urge the government to regulate tobacco advertising. ${ }^{16}$ This resulted in a ban on advertising on radio and television in 1980 through the Media Act. Parliamentarians also became impatient with respect to smoking bans. Again the CDA tried to speed up the process ${ }^{17}$ by tabling a motion to ban smoking in public places. ${ }^{18} \mathrm{~A}$ year later this was followed by another motion from the CDA requesting the same, referring to the fact that France had implemented a ban on smoking in public places since July. ${ }^{19}$ These motions were the start of an almost decade-long process leading to a public smoking ban, the main element of the Tobacco Act of 1988.

The ICBT reported to the state secretary for health in January 1981 (ICBT, 1981). The recommendations were more industry-friendly this time around than the previous reports; compromise was sought between health and economics. The committee identified four principles as starting points for tobacco control policy in declining order of significance: tobacco use is harmful for health; youth need to be protected; the right of physical integrity in non-smokers has to be balanced against the right of personal 
freedom of smokers; and undesirable societal and economic consequences must be taken into account. The committee underscored this last principle by writing that it was aware that the tobacco sector contributes significantly to the national economy. The idea of a tobacco advertising ban was postponed indefinitely because the commission felt that the industry must be allowed to use advertising as a means of "communicating" with their consumers about new products. The committee did criticise the existing self-regulation (the Reclame Code) for lack of sanctions and recommended that misleading advertisements should be sobered down, for example, through restrictions on the use of colours. The idea of deterring smoking through higher cigarette taxes (either by increasing general taxation levels or by linking the tax level to the level of harmful substances so that more harmful products would be taxed higher) was considered, but no concrete proposals were made. The most far-reaching recommendation was to restrict the number of tobacco selling points to specialty shops, but since this could have substantial consequences for the tobacco sector it was not to be done hastily, according to the committee. Other proposals were to ban tobacco vending machines and to ban smoking in public places and in government buildings. The ICBT report remarked that in a future Tobacco Act, regulation might be included to limit the quantity of substances that were harmful to health in tobacco products. In April 1981 the ICBT was asked by the state secretary for health to work out the details of a Tobacco Act, while parliament was disappointed that five years after the Meulblok Committee, nothing had been accomplished except further pointless deliberations and slow-down tactics by the industry. ${ }^{20}$

Piet van Zeil, the state secretary for economic affairs in the first Lubbers cabinet (1982-1986), discussed the idea of restricting the sale of tobacco products to specialty shops in parliament in August 1982. Van Zeil promised he would have another round of talks with the business community to hear their side of the argument. ${ }^{21} \mathrm{He}$ felt that for each measure (a ban on vending machines and restricting points of sale), costs and benefits needed to be balanced, and indications that measures could pose a burden on businesses had to be taken seriously. He pointed out that this cabinet was not likely to opt for a broad reduction of the number of sales outlets, nor even for a ban on vending machines. The Lubbers cabinet's motto was "more market, less government."

In July 1983 the cabinet gave the green light to the idea of promulgating a Tobacco Act. At the end of 1984, State Secretary for Health Joop van der Reijden and State Secretary for Economic Affairs Piet van Zeil sent 
a proposal to parliament for consideration..$^{22}$ In the introductory remarks of their clarification document, the two underlined the importance of economic considerations ${ }^{23}$ :

Against the interests of public health, that have to do with the reduction of smoking and the protection of non-smokers, are economic and fiscal interests that have to be taken into consideration as well. Thousands of citizens earn their daily bread, or at least part of it, from the production and distribution of tobacco products. Smoking is a deeply ingrained and socially accepted habit, although there are clear signs that this acceptance is diminishing. The state enjoys considerable revenues from tobacco taxes, which are used to finance many useful and necessary things.

The government gave the industry the benefit of the doubt by continuing the policy of self-imposed restrictions on tobacco advertisements. Only if this did not have the expected effect on youth smoking would the government consider imposing a ban by decree-but it did not specify how they would evaluate the effectiveness of self regulation.

The ICBT's proposal to reduce the number of tobacco selling points was not part of the proposal for the Tobacco Act, "because the harmful effects on the business community, especially middle and small businesses, cannot be sufficiently compensated." 24 Only the sale of tobacco in healthcare institutions and educational facilities was to be restricted. The proposal to ban the sale of tobacco to minors and to ban vending machines was also abandoned, because the government wished to follow the advice of a "deregulation" committee (see also Chap. 5 on the importance of deregulation committees), which made the point that such a ban would be difficult to uphold and easy for minors to circumvent. With respect to a smoking ban in public places, the government did not want a general ban, but instead left it to local administrators to decide on the best way to protect non-smokers from second-hand smoke and how to decide which local areas should be subject to smoking restrictions. The ban was restricted to government-owned buildings and buildings of organisations that worked for the government, such as hospitals, schools, and social welfare organisations. The government wanted to leave open the possibility of restricting smoking instead of banning it completely, for example, by tolerating smoking in designated sections or during designated hours. What was to be the centrepiece of the Tobacco Act became a disputable and vague instruction to the managers of public buildings, with no sanctions provided for viola- 
tions. Borgman, the CDA parliamentarian behind the motion from 1980, summarised the general feeling of disappointment among parliamentarians: "the submitted Tobacco Act has, after going through the bureaucratic wheels of interdepartmental consultation, deregulation and so forth, more the appearance of a leaflet with suggestions and prescriptions than the ground-breaking law that the parliament has been asking for since 1977." 25 Parliamentarian Erwin Nypels (Democrats 66) proposed an amendment to include private workplaces in the smoking ban. ${ }^{26}$

In July 1986, when the second Lubbers cabinet (1986-1989) came to office, the new State Secretary for Health Dick Dees (VVD) at first was open to the amendment, but after some pressure from the employer organisation Verbond van Nederlandse Ondernemingen en Nederlands Christelijk Werkgeversverbond (Confederation of Netherlands Industry and Employers) (VNO-NCW), ${ }^{27}$ advised against it. ${ }^{28}$ In his national policy document on prevention of heart disease, State Secretary Dees did not announce further tobacco control measures. ${ }^{29}$ The cabinet did not want to include smoking restrictions for private workplaces in the new act, and opted for the path of continued self-regulation instead. This meant reaching agreements with the business community through talks and negotiations with the "social partners" (the employee and employer organisations).

During the final debate in the senate, State Secretary for Health Dick Dees (VVD) admitted that he was still negotiating with the industry about a satisfactory code of conduct for tobacco advertising. ${ }^{30}$ The industry accepted the conditions for self-regulation just before the Tobacco Act was published in the Bulletin of Acts. A new advertising code of conduct was decided upon and entered into force on 1 January 1989. It was agreed that this would last for another five years. Although the Tobacco Act included the threat of prohibiting advertising through an Order of Council, it did not come to this. Occasionally, the industry made small adaptations to the advertising code to accommodate calls for tighter restrictions by parliament and health organisations. This situation would continue for another decade. Protected by their code, tobacco industry spending on advertising increased from 21 million guilders in 1974 (Beernink \& Plokker, 1975) to 35 million in 1977 (Algemene Rekenkamer, 1982) and to more than 200 million in 1996. ${ }^{31}$ The Tobacco Act included a ban on tobacco advertising on radio and television, to comply with European Union (EU) regulations (Directive 89/552/EEC). This was no improvement, since advertising on TV and radio had already been banned since $1980 .^{32}$ 
The final verdict of the senate in March 1988 was that the piece of legislation was too little, too late, and could not be expected to affect smoking rates. The senate supported it nevertheless, for lack of something better. ${ }^{33}$ The Tobacco Act was approved on 10 March 1988 and went into effect on 1 January 1990, after four years of deliberations, debates, and amendments. It is a framework legislation, where specific details may be decided on at a later stage through ministerial decisions and governmental decrees. What was accomplished was that smoking was more or less banned (leaving open the possibility of smoking sections and smoking during designated times) in about 50,000 indoor venues in governmentowned buildings and properties open to the general public.

In response to the general disappointment and discontent with the weak act, the government decided to intensify education, campaigns, and palliative measures to appease the health lobby for a while. A working group was installed to develop a multiple-year educational programme. The government's subsidy to STIVORO for campaigns increased somewhat from 1989 onwards, and STIVORO was commissioned to start a mass media campaign to motivate private companies to implement smoking policies on a voluntary basis.

During this time, the government asked the Health Council to reassess the harm from passive smoking in light of new evidence from abroad. The report was presented in 1990 but lacked firm conclusions about causal associations between prolonged exposure to passive smoking and the risk of lung cancer (Gezondheidsraad, 1990), which did not help put proposals for further restrictions on smoking on the political agenda (see Chap. 9 for a further discussion of this report and the relatively late official recognition that passive smoking is a public health problem in the Netherlands).

\section{Policy Stagnation (1991-1994)}

For some time the 1988 Tobacco Act remained the final governmental response to the tobacco problem. The third Lubbers cabinet (1989-1994) had a new state secretary responsible for tobacco control: Hans Simons (Labour Party). Simons commissioned Research For Policy, a commercial research firm, to evaluate the effectiveness of the Tobacco Act. He wanted to know whether the self-regulation of tobacco advertising and promotion by the industry was effective, and whether the new measures in the act were sufficient to protect youth and non-smokers. The conclusions of the 
report, published in September 1991, were that the code of conduct and the new Tobacco Act had had no detectable effect on the smoking habits of the Dutch (Dresscher, Elzinga, \& Koldenhof, 1991). The researchers identified weak spots in the policy and considered it "ambivalent" because of the government's wish to accommodate the irreconcilable interests of health and economy. This resulted in advertising restrictions that were not comprehensive, smoking bans that offered little protection to nonsmokers, and rules and regulations that were rarely adhered to. The industry spent more money on tobacco advertising than ever before and managed to sell more cigarettes per smoker, so that "the result is a policy that is neither fish nor fowl, its effectiveness largely depending on public norms" (Dresscher et al., 1991, p. 76). Despite these harsh comments, Research for Policy did not recommend a full advertising ban, anticipating attempts by the industry to circumvent any such ban. Instead they advised a middle way: extending the existing set of self-imposed measures and investing more in enforcement.

In a letter to parliament, State Secretary Simons, inspired by the report, was critical of the national tobacco policy of previous cabinets. ${ }^{34} \mathrm{He}$ noted that the Netherlands lagged behind other European countries and criticised the tobacco industry's attempts to circumvent their own advertising restrictions, saying that he wanted to intensify national tobacco control policy. He noted that the self-regulative measures of the tobacco industry in the United Kingdom and Denmark were stricter than in the Netherlands. For example, in the United Kingdom, the industry refrained from positive images in advertisements, such as Marlboro's tough cowboys. He proposed a substantial tightening of the advertising code of conduct, including more restrictions on advertisements and a ban on indirect advertising in radio and television programmes, and he wanted to examine the option of restricting smoking in private workplaces through legislative measures, as three quarters of private workplaces had no relevant smoking policy. These proposals were accompanied by two press releases. One carried the title "Self-regulation tobacco advertising insufficient" (VWS, 1991), the other "Tighter approach to tobacco policy" (WVC, 1991).

The tobacco industry was furious, and quickly commissioned a competing research firm to produce a detailed critique of Research For Policy's report, refuting the minister's accusations that the industry was not abiding with the code of conduct (Nederlands Economisch Instituut, 1991). The position of the Ministry of Economic Affairs was that Simons had to give the industry's advertising code the benefit of the doubt, and civil 
servants from that ministry suggested that if no agreement with their bureaucratic counterparts at the Ministry of Health was possible, Economic Affair's Minister Koos Andriessen would have to talk sense to Simons (Ministerie van Economische Zaken, 1991). Although Simons stated that tobacco control was a "very high policy priority," 35 he gave in to the pressure and failed to make any advance in tobacco control policy.

The Dutch cabinet reconfirmed its preference for self-regulation over a legislative approach. ${ }^{36}$ A compromise was reached between Hans Simons and the Minister of Economic Affairs that the government would not start the process of drafting a ban but would instead continue to work with the industry to increase their self-regulating efforts. ${ }^{37}$ The initiative to protect non-smoking employees at the workplace was left to Stichting van de Arbeid (the Labour Foundation) (STAR), which decided not to consider a ban but to allow labour representatives and management of individual businesses to reach mutually satisfactory policies (Stichting van de Arbeid, 1992). ${ }^{38}$ In practice this meant that if individual non-smoking employees had an issue with smoking at their workplace, and were unable to find a satisfactory solution with their colleagues and their employer, their only option was to take their employer to court. They would have to point to relevant passages in national occupational health and safety legislation-an almost impossible task for the average worker.

Heated fights and debates over the voluntary advertising agreements characterised the first part of the 1990s. While the ministries negotiated regularly with the industry about the advertising code of conduct, health organisations publicly declared its failure. Pressure on the government increased when the parliament tabled a motion for an advertising ban. ${ }^{39}$ Simons started the process of drafting an amendment to the Tobacco Act that would open the door to an advertising ban, in case the industry's selfimposed restrictions were not satisfactory. The code of conduct was regarded as "the last chance that the cabinet offers to the industry in the way of self-regulation." ${ }^{40}$ A new code went into effect on April 1994 and resulted in minor improvements, such as advertisements no longer depicting persons looking younger than 30 , and no tobacco ads run in cinemas before 6PM. In addition, the industry agreed that it would not increase its total spending on tobacco advertisements above the level reached in 1990. It was agreed that the new code would be in place for another five years and would be evaluated every six months, not only for industrial compliance, but also for whether the industry was adhering to the spirit of the code, which was to keep all promotion of tobacco products away from children. 
Protesters against the advertising code of conduct had support from the European (EC), which had proposed an EU-wide advertising ban in 1991. However, this had been successfully opposed by a group of member states, including the Netherlands, which raised legal objections and argued that EU legislation was not acceptable if an issue could be better addressed at the national level (the so-called subsidiarity principle; see Chap. 5). In 1994 the health warnings were improved slightly with "Smoking seriously harms health" replacing "Smoking threatens health."

\section{Tobacco Control Proposals by Minister Borst}

\section{(1994-1997)}

In August 1994 the so-called Purple Cabinet came to power. This was a coalition between two liberal parties (VVD and Democraten 66 (D66), both "blue") and the "red" Partij van de Arbeid (Labour Party) (PvdA), hence the name "purple." It was relatively progressive, with only five VVD ministers against a prime minister from the Labour party, four additional Labour ministers and four D66 ministers. Els Borst (D66) was the first minister of health in Dutch history. Before her, state secretaries were responsible for public health. She had personal motives to fight smoking: she was the sister-in-law to a leading Dutch cancer specialist, and on entering office was already over 60 with a long career as a practising physician and director of an academic hospital. She had also been vice president of the Health Council. Borst had a strong position in the cabinet and a good working relationship with both the Prime Minister Wim Kok and with Hans Wijers, the Minister of Economic Affairs, who was from the same liberal-democratic party as she. ${ }^{41}$ D66 had written in its election programme that the Netherlands was a European backbencher regarding restrictions on tobacco advertising, and that it should catch up as soon as possible.

Borst highlighted the urgency of tackling smoking in her disease prevention policy document, Gezond en Wel, launched in March 1995. ${ }^{42}$ She characterised the Dutch tobacco policy as "mild" and made the point that anti-tobacco regulation had fallen behind other countries in Europe. She identified tobacco control as a priority for the government and announced her intention to "intensify" it. In a letter to parliament she explained that the "proven effectiveness" of a policy was an important criterion when choosing the right measures to tackle tobacco. ${ }^{43}$ She wanted to limit the availability of tobacco products to minors, sharpen the smoking ban in 
public places by installing sanctions, intensify anti-tobacco youth education and smoking cessation efforts, and evaluate the current tobacco taxation level in light of European minimum standards. These proposals were not particularly ground breaking nor were they threatening to the industry-in her first years in office, Borst, a liberal politician and part of a coalition with the liberal-conservative VVD, was searching for measures that would have political support from liberals. Most parties in parliament, except VVD and CDA, rejected the weak proposals. Instead, they wanted the government to make the decision to ban advertising sooner and endorsed the need for the government to support stricter advertising regulation by the EU. ${ }^{44}$

Regarding advertising restrictions, Minister Borst was confronted with a major obstacle. The government had recently renewed its agreement with the industry for a new five-year period of self-regulation, promising that there would be no regulation as long as the industry adhered to the code of conduct. Borst ordered the state attorney to examine whether the government could unilaterally withdraw from these agreements with the industry, so that the route to an advertising ban would be open. This turned out to be very difficult, since the agreement had legal power and could only be overturned if the advertising code was not adhered to "in letter and in spirit" (De Landsadvocaat, 1995). Borst proposed a limited list of acceptable types of advertising, instead of working from the current extensive set of restrictions. This was because poorly formulated restrictions were relatively easy for the industry to circumvent, evidenced by a plethora of incidents in which the industry continued to promote its products to young people.

In January 1995, the industry refrained from advertising on billboards in the direct vicinity of hospitals and schools, and the fine for violating the code of conduct was increased from 50,000 to 100,000 guilders. ${ }^{45}$ In 1996 the industry ended tobacco commercials on cinema screens. Despite these small improvements, tobacco advertising was still omnipresent-in magazines, on billboards, and through brand stretching and the promotion of brand logos at music festivals. The industry continued to broadcast commercials in cinemas for Mascotte cigarette-rolling paper and the Camel Trophy challenge. Tobacco promotion at the international Formula 1 Grand Prix racing in Zandvoort and the TT motor racing in Assen continued as well. During this period smoking rates went up, with a dramatic increase from $36 \%$ (1989) to $39 \%$ (1996) in the male population and from $29 \%$ to $32 \%$ in women (STIVORO, 1999). 
In the autumn of 1995, Borst visited the Department of Health of the United States and was impressed by American tobacco control policy. Strengthened by the visit, she ordered her civil servants to write a comprehensive tobacco control policy. On 28 May 1996, she sent a letter to the parliament detailing her tobacco policy intentions (nota Tabaksontmoedigingsbeleid): "in light of the grave consequences of tobacco use, tobacco policy needs to be strengthened." 46 The document contained five major policy intentions. The first was to allocate more money to STIVORO's youth education activities, particularly to STIVORO's campaign "Smoking, a deadly sin," ${ }^{47}$ which confronted youth with the shortand long-term health consequences of smoking. A second intention was to tighten the existing tobacco promotion restrictions. The document contained a new set of detailed self-restrictions that had been agreed upon by cabinet and industry after extensive negotiations over half a year. They were intended to keep tobacco advertisements further away from children, including no advertisements in cinemas and in the vicinity of schools, nor in magazines read by children. A third policy intention was to extend the public smoking ban to institutions in the culture and art sector, and to private companies with a public function, such as public transport and post offices. This would bring Dutch regulation in line with EU Resolution $89 / \mathrm{C} 189 / 01$ that invited member states to implement smoking bans in public places, including public transport. In addition, the supervision of the smoking ban in public places, which was not well complied with, was to be tightened. The problem with the smoking ban was that the supervisory authority could impose neither sanctions nor fines for non-compliance (Verdonk-Kleinjan, 2014, p. 17). A further problem was that since the Tobacco Act had come into force, organisations were allowed to permit smoking in one-third of their space or one-third of the time. The fourth policy intention was to ban tobacco sales to youth under 18 . The fifth was to use tobacco excise duties as a means to reach tobacco control goals. This was an important step: until then, levying tobacco excise duties had been regarded by the government solely as a means to generate revenue, but from 1996 it came to be considered a valid "secondary effect" of tobacco taxes (Visser, 2008, p. 157).

A working group with experts from the ministries of health, trade, and finance was commissioned to make a proposal for price increases. Three months after her nota Tabaksontmoedigingsbeleid, Borst announced in a letter to parliament that tobacco tax would be raised in such a way that the new price of a pack of cigarettes ( 25 sticks) and a pack of roll-your-own 
tobacco would be 50 cents higher, ${ }^{48}$ and that "with this measure a comprehensive package of policy measures to discourage tobacco will be accomplished."

In 1997 Borst changed her position on tobacco advertising. ${ }^{49}$ She no longer wanted to prolong the gentlemen's agreement between government and industry and announced a ban on all tobacco promotion, declaring that the Netherlands would no longer block the EU's advertising directive. The new Labour Government in the United Kingdom had stopped resisting the EU's advertising ban, and the Dutch government was able to follow the English example (see Box 6.1 in Chap. 6).

In the meantime, on 29 October 1996 the parliament adopted two resolutions. ${ }^{50}$ One was proposed by parliamentarian Rob Oudkerk (Labour Party), requiring the government to make preparations for a ban on outdoor advertising; the other was by Jan Marijnissen (Socialist Party), requesting that the government restrict the sale of tobacco to specialty shops. Other motions were tabled in the same meeting: vending machines had just been banned in the United States, and Dutch parliamentarians mentioned this as an example for the Netherlands to follow. This resulted in a held motion (by Oudkerk and others) to ban vending machines in bars and cafés frequented by young people. ${ }^{51}$ During the same plenary session, parliament also adopted a motion from the liberal-conservatives (VVD) to renounce tax increases. ${ }^{52}$

\section{Drafting a New Tobacco Act (1998-2002)}

In August 1998 the second Purple Cabinet was installed, with Els Borst again as Minister of Health. The coalition agreement contained an explicit goal to implement the European tobacco directive when the current code of practice ended in May 1999. Borst commissioned the Netherlands School of Public Health (NSPH) to examine the effectiveness of various policy options. Borst asked the NSPH to assess the full range of policy options, including education, sale restrictions, advertising restrictions, tobacco taxation, smoking bans and product regulation. She also wanted to know what the impact of tobacco policy would be on both public health and the economy. The report supported a comprehensive policy approach to tobacco control (Roscam Abbing, 1998). It made clear that isolated measures had little effect, and needed to be part of a comprehensive strategy so they could reinforce each other. An important conclusion was that "a specific combination of measures [would] give the government the 
ability to have the greatest impact." The NSPH report became an important building block for the new Tobacco Act. Borst's proposal for a revision of the Act was sent for first consideration to parliament in April 1999. ${ }^{53}$ The main conclusion from the NSPH report, that a comprehensive approach was needed and that leaving out specific measures would weaken the policy, was repeated in the explanatory memorandum to the bill. ${ }^{54}$ Borst remarked that considering that smoking trends were not going down, the WHO target of $20 \%$ smoking in 2000 was not feasible, "and because the situation in the Netherland does not compare favourably with our European partners, the researchers stress that a more intensive deployment of policy measures is required."

The NSPH report included a study on the societal costs and benefits of comprehensive tobacco policy (Van Leeuwen \& Sleur, 1998). Borst learned from this that any negative economic effects on tobaccoproduction related sectors would be compensated by increased productivity in other sectors of the economy, and that the resulting macro-economic effect could even be positive. This conclusion was in line with the landmark Curbing the Epidemic report, published a month later by the World Bank, that concluded that tobacco control achieves unprecedented health benefits without harming national economies (World Bank, 1999). In a meeting with the minister of Finance, Borst used both reports to convince him that a tobacco tax increase in 2001 was a necessary part of the tobacco control policy package (Kalis, 2000). When comparing this 1998 explanatory memorandum to the 1984 one (which accompanied the proposal to the first Tobacco Act) ${ }^{55}$ what stands out is the emphasis on public health and a lesser preoccupation with economic objections. Negative effects on the commercial activities of the tobacco industry were accepted as inevitable. Borst made this point clear again in 2000, in a reply to questions by the VVD about the economic effects of her tobacco control proposals. ${ }^{56}$ She argued that tobacco control gradually leads to less consumption of tobacco products and more spending on other goods, resulting in a displacement of the production pattern in the economy in such a way that there would be a new equilibrium-much the same as the old situation in macro-economic terms - but far better for health: "less smoking is good for public health and certainly not bad for the economy: we will all gain."

In May 2000, Borst attended the annual meeting of the World Health Organisation (WHO) in Geneva and spoke at length with Gro Harlem Brundtland, its director. In an interview with a reporter of the Dutch morning newspaper De Telegraaf, Borst announced rigorous measures 
against tobacco (De Jong, 2000). Now that there had been a court decision in the Nooijen case, where an employee had successfully litigated for a smoke-free workplace (see Chap. 9), she felt that it was time for a legal prohibition on smoking in the workplace so that non-smoking employees no longer had to take their employers to court. She also wanted the sale of cigarettes restricted to specialty shops. In the interview she hinted at a complete end to tobacco, and threatened to ban tobacco production from Dutch soil: "This means that there will no longer be any future for Philip Morris in the Netherlands. If you don't want future generations to smoke, we shouldn't be producing cigarettes in this country." This declaration of war against the tobacco industry became headline news.

On 30 May 2000 Borst sent her proposal for a revision of the Tobacco Act for approval to Parliament. ${ }^{57}$ This was four years after she had presented her policy intentions and two and a half years after her bill was debated upon in Parliament. In reply to displeased parliamentarians about why it had taken so long, she answered that it was because of consultations with the industry and discussions within the cabinet. ${ }^{58}$ The proposal was subject to lengthy debates in parliament for another two years, in which it was changed several times because of amendments (nine in total) and motions (seven in total) from both chambers of parliament.

The original proposition for a revised Tobacco Act contained a proposal for a workplace smoking ban, but this was removed after discussion in cabinet. Instead, the proposal sent to parliament for approval included a conditional ban on smoking in shared workplaces in the private sector, which would only come to life if the social partners (employers and employees) were unable to come up with improved self-regulation measures. The government proposed to settle this through an order-in-council that would give the social partners another year to prove they could protect employees from tobacco smoke without needing a ban. Until then controls on smoking in private workplaces had been left entirely to labour and employer representatives who negotiated in STAR. In 1997 the Ministry of Social Affairs evaluated whether this arrangement still worked, and concluded that it did not: at the end of that year only $28 \%$ of private companies had some sort of policy in place to protect employees (Spijkerman \& van den Ameele, 2001).

Borst proposed changing the Tobacco Act in such a way that it would include a complete ban on tobacco advertisements and sponsorship, improvements to existing sale restrictions, an age limit for the sale of tobacco products (18 years), and administrative monetary penalties for 
infringements. Since her proposal did not have a plan to phase out tobacco selling points, as requested by Socialist Party MP Jan Marijnissen, Agnes Kant (Socialist Party) tabled a new amendment to restrict the sale of tobacco to specialty shops. ${ }^{59}$ When a motion with majority support from parliament is not acted on by the government, the government needs to explain why, and be prepared to confront parliament on the issue. Although Borst clearly wanted to restrict tobacco sales to specialty shops and felt she was supported by the NSPH report, which made a strong case for restrictions on tobacco sale, the cabinet could not come to an agreement about how to respond to the motion. ${ }^{60}$ Borst translated the cabinet's stance in a rather cryptic answer to the parliament: "the government has not decided that it will not carry out the motion by Marijnissen and therefore it has not made this explicitly known." Sometime later, the Green-Left party (MP Corrie Hermann) tried to introduce into the act a gradual restriction on tobacco sales to specialty shops, cafés, and bars, with an amendment that proposed to do this through an order-in-council. ${ }^{61}$ Neither amendment made it into the final text of the Tobacco Act. The idea of sale restrictions was postponed for consideration as part of a new tobacco control policy proposal (Tabaksnota II), by the next government.

On 31 May 2001, appropriately World No Tobacco Day, the proposal for the amendments to the Tobacco Act was discussed in the second chamber of Parliament. ${ }^{62}$ The debate lasted almost 12 hours. The parties on the right flank (CDA, VVD) argued against a smoking ban and an advertising ban. The CDA called the bill "too detailed and patronizing." Several amendments were proposed, and led to two major changes to the bill. The first was to set the age limit for buying tobacco from 18 to 16 years (amendment by the Green-Left party and D66). ${ }^{63}$ This may be considered a success for the tobacco industry network, because of their 1998 preemptive initiative to voluntarily implement a restriction not to sell to youth under 16 (slogan: "There is no excuse. We only sell above 16 years of age"), and initiatives to restrict the access of minors to vending machines. Following anecdotal evidence that an 18-year age limit was difficult to enforce, parliamentarians believed that 16 would be more effective-and at that time, the sale of beer and wine was also set at 16 years. The second change was the more important one: a direct smoking ban in private workplaces instead of continued self-regulation. This was the result of an amendment proposed by Corrie Hermann of the Green-Left party, ${ }^{64}$ who was stimulated to table the motion by a strong lobby from the health network led by STIVORO, supported by Clean Air Netherlands (CAN) and 
the Lung Foundation. Part of the lobby was in the form of media attention to two court cases in 2000, the first initiated by an employee of the Royal Post (Nanny Nooijen) who successfully litigated for a smoke-free workplace. The other was by the mother of Nienke Hora Adema, a mentally disabled young woman. She had successfully demanded smoke-free living quarters for her daughter in the epilepsy institution Cruquiushoeve. The majority of parliament agreed with Borst that it should not require a court case each time an employee had a problem with tobacco smoke in the workplace, and the problem could better be resolved with a law. The revised Tobacco Act signified a breach with the long-term status quo where smoking restrictions in private workplaces were left to the discretion of STAR. ${ }^{65}$ However, it also included a clause that made it possible to exempt certain categories of employers. This was primarily included with a view to exempting the hospitality sector, but it was possible for other categories as well, and further left open the option to stretch the time of implementation to give society ample time to adapt to the new law.

The CDA tabled a motion to the effect that the government would allocate 30 million guilders for education campaigns: only under this condition was CDA prepared to support the Act. The motion was not adopted. The amendments to the Tobacco Act were adopted in the lower house of parliament on 6 June, ${ }^{66}$ but with CDA and VVD voting against. The CDA felt the act was "too elaborate and too paternalistic" and would fail to change smoking behaviour as it did not include the necessary funds for prevention and education. The VVD argued that it could not support a bill which made the government responsible for protecting people from tobacco smoke instead of leaving it to employer and employee organisations.

On 16 April 2002, after a lengthy and difficult debate, a majority in the senate adopted the bill as well. This was not an easy win for the minister, since the CDA and VVD together held a majority position in the senate, and both parties had voted against the bill in the lower house. In the senate the CDA voted in favour, but only on the condition that $€ 15$ million would be made available for mass media campaigns and support for smokers who wanted to quit smoking once the ban came into force. Most parties seconded a motion by Christian Democrat Jos Werner to this effect. ${ }^{67}$ Another condition was that the government would agree to discuss exceptions to the smoking ban and exact enforcement dates with affected societal organisations. This resulted in agreements with the national sports federation (NOC $\times$ NSF) and Koninklijke Horeca Nederland (trade organisation for the hotel and catering industry) (KHN) on trajectories of self- 
regulation. Details of the implementation of the smoking ban were discussed with STAR, leading to the decision to implement in 2004 instead of 2003.

On 18 April 2002 the revised Tobacco Act was published in the Bulletin of Acts. On 28 June 2002, Borst signed an order-in-council stipulating when the different articles of the revised act would enter into force. The advertising and promotion ban went into effect in November 2002, although newspapers and magazines were granted a stay until January 2003. The 16-years age-of-sale was in effect from January 2003 as well. The legal right to a smoke-free workplace and smoke-free public transport took effect on January 2004, while the government allowed nursing homes and homes for the elderly to implement the smoking ban in 2005 . Three weeks before the cabinet resigned, Borst managed to implement an important element of the first EU Tobacco Products Directive (TPD-1): cigarette packs had to carry warnings that covered $30 \%$ of the front of the pack and $40 \%$ of the back, with rotating texts. This came into effect on the first of May 2002-remarkable, as this was four months before the date required by the European Commission (EC) and sooner than any other EU country. Other aspects of TPD-1 could not be transposed in Dutch law through an order-in-council, but required a revision of the Tobacco Act itself. This was left to the new cabinet.

\section{An Ambitious New Tobacco Control Policy Document That Never Made It}

In 2000 Minister Els Borst had prepared a second tobacco control policy paper with significant new policy steps. ${ }^{68}$ Details followed a year later, during long debates in both chambers of Parliament. ${ }^{69,70}$ The ambitious new tobacco policy document, entitled Together towards a Smokefree Society (VWS, 2001), contained proposals for considerable increases in tobacco taxation, anti-tobacco marketing campaigns targeted at youth that were budgeted at 30 million guilders per year, ${ }^{71}$ and a clear policy intention to restrict the distribution of tobacco products in such a way that tobacco would eventually be sold in specialty shops only (in line with Marijnissen's motion and the amendments by Agnes Kant and Corrie Hermann). This was discussed with representatives of the tobacco industry sector and the health sector in a meeting in The Hague, but never made it into a formal proposal for a new law. Although parliamentarians challenged Borst about 
Tabaksnota II, as it was called in parliamentary debates, ${ }^{72}$ she was unable to secure the necessary budget. She hoped that the next government would take it up, but this never happened.

\section{Transposition of the EU Tobacco Product Directive INTO THE TOBACCO ACT (2002-2003)}

In July 2002, the first Balkenende cabinet came to power. This was a cabinet consisting of the CDA, VVD, and a new populist right-wing party Lijst Pim Fortuyn (LPF). The LPF was built around the legacy of Pim Fortuyn, a charismatic populist politician who had been assassinated the year before. This cabinet lasted 86 days and collapsed after internal conflicts in the LPF. In this cabinet, economist and former Labour Party member Eduard Bomhoff was minister of health for the LPF. He was not a tobacco industry-friendly minister, and after being bombarded with letters and requests for meetings by the industry when he took office, he publicly distanced himself from tobacco lobbyists. Once during a debate on tobacco policy in parliament he spotted a tobacco industry lobbyist in the public gallery sitting right across from him, which he felt intimidating. ${ }^{73} \mathrm{He}$ raised his voice and said, "I see a lobbyist at a distance of 30 meters from where I stand, and that distance seems a very good one to keep!" 74 Bomhoff, at his very first cabinet meeting, managed to make the weekly cabinet meeting smoke-free. Smoking had been banned in meeting rooms since 1990, but in the most important meeting room in the country the smoking ban was not yet complied with. Several ministers were ardent smokers, including Minister of Finance Gerrit Zalm, and Minister of Internal Affairs Johan Remkes (both VVD).

Eduard Bomhoff inherited two important tasks: implementing the new Tobacco Act and transposing the remaining elements of the TPD-1 into national law. He was not able to make significant steps regarding the first task as the cabinet had already disbanded, but the transposition of the TPD-1 was more pressing and could not wait. The final date on which all components of the directive had to be transposed into national law had been set by the EC as 30 September 2002. There were several obstacles. One was an issue brought forward by the CDA and VVD: the protection of tobacco industry company secrets in light of TPD's requirement that tobacco producers submit and publish lists of the ingredients 
in their products. The government remained steadfast that it would implement the TPD-1 requirements, despite industry protests. It accepted the risk of being taken to court by the industry, which eventually happened. Partly because of a change of government, the interim cabinet was unable to achieve the EU deadline. An additional problem was that the interim government failed to secure the $€ 15$ million for tobacco prevention education in the ministry's budget, despite Werner's motion to this effect and promises made to the parliament. This meant that the senate was not prepared to approve the amendments to the Tobacco Act that were necessary to transpose the TPD-1. ${ }^{75}$ Acting Health Minister Clémence Ross-van Dorp, who stood in for Bomhoff in the interim cabinet, succeeded in scraping together $€ 10$ million from the budget ${ }^{76}$ still an unprecedented amount of money for tobacco prevention in the Dutch context. This was enough to satisfy the senate. The decision to make this a structural, yearly tobacco education budget was left to the new cabinet (Balkenende II), where it stalled. The revision of the Tobacco Act to accommodate the TPD-1 requirements was approved by the senate on 28 January 2003 .

\section{Implementing the Tobacco Act (2003-2005)}

At the end of May 2003, the Balkenende II cabinet replaced the failed first Balkenende cabinet. Former Minister of Finance Hans Hoogervorst (VVD) succeeded Bomhoff as the minister of Health. Balkenende cabinet II wanted to diminish the role of the central government further and decentralise prevention and cure. In June 2003, during a debate with the second chamber of parliament, Hoogervorst said that Tabaksnota II would be part of his disease prevention policy paper. ${ }^{77}$ This was a nondescript prevention programme with a few tobacco control policy intentions. In this way, the ambitious Tabaksnota II was silently killed without protest from politicians or from civil society.

Hoogervorst's prevention programme had a quantitative target for tobacco control: $25 \%$ smokers in 2007; but it announced no new tobacco control measures, nor was extra money set aside for tobacco prevention (VWS, 2003). It was assumed that the target of $25 \%$ smokers in 2007 could be reached by implementing the existing measures (smoking ban in workplaces in January 2004, implementation of mass media campaigns financed through the "Werner money," and strict enforce- 
ment of the age limit for the sale of tobacco and of the advertising and sponsorship ban), supplemented with a mass media campaign targeted at youth. For $2004, € 5$ million extra were allocated for educational campaigns, in addition to the ten million already set aside by the Werner motion.

A later date of implementation of the smoking ban in the hospitality sector was negotiated with employer and employee representatives through STAR, and with organisations representing employers and employees in the hospitality sector. The food and drinks catering sector was granted a period of self-regulation to make bars and restaurants smoke-free before the end of 2008. If this covenant failed, a ban would be implemented in bars and restaurants. This was one year sooner than Tony Blair's UK government's timeline. The UK Department of Health published a white paper on public health in November 2004, stating the intention to make workplaces, including restaurants and pubs which prepared and served food, smoke-free, through a staged approach ending in late 2008 (Department of Health, 2004). At that time very few countries in Europe had smoking bans in bars, or even in restaurants. In 2004 Ireland became the first European country with a comprehensive smoking ban in the hospitality sector, soon followed by Malta, Italy, and Norway (WHO, 2006). Most countries still had voluntary agreements, or limited or no restrictions.

The commercial sports sector in the Netherlands wanted exceptions similar to the smoking ban in sports canteens negotiated between the government and the hospitality sector. Hoogervorst came to an agreement with sportsfederation NOC $\times$ NSF to commence a two-year trajectory of self-regulation (until 2006) so that commercially run sports canteens would gradually become smoke-free. ${ }^{78}$

In November 2003, parliament debated the implementation of the workplace smoking ban with Hoogervorst, ${ }^{79}$ shortly after the Health Council had published a second report on the health risks of passive smoking (an update of the 1990 report). The new report estimated that 2000 smokers were killed each year by passive smoking (Gezondheidsraad, 2003). Instead of underscoring the need for strict regulation without exceptions, parliament was sceptical of the report's conclusions, spurred by an attack on the report by a libertarian journalist in newsmagazine $H P / D e$ Tijd and parliamentary questions from the Socialist Party. ${ }^{80}$ 
VVD Member of Parliament Edith Schippers tabled a number of motions, together with the Socialist Party and the LPF, to weaken the smoking ban. ${ }^{81}$ Seven out of nine received majority support. ${ }^{82}$ There was support (including from the Labour Party and the Green-Left party) for a motion to give institutions in the mental health sector and other sectors where people lived in private accommodations, such as homes for the elderly and nursing homes, the possibility of self-regulation instead of a ban. Other motions receiving majority support from VVD, LPF, CDA, D66, and SP, requesting that the government come up with proposals to explore the viability of ventilation techniques and smoking sections as alternatives to bans in the food and drink sector, to extend the selfregulation to commercially run bars and canteens in sporting facilities, to choose a broader definition of "hospitality sector" so that amusement arcades and cinemas would be included, and to wait until the end of the self-regulation period for the hospitality sector before deciding if and when its exception status would come to an end. The government was requested to determine the success of self-regulation based on a set of "reasonable norms" for air quality and criteria for exposure to secondhand smoke. A motion to consider allowing smoking in coffee shops was supported both by the left (SP, Labour Party) and liberal parties (D66, VVD, LPF). The minister, however, rejected the motion..$^{83} \mathrm{He}$ argued that coffee shops were part of the hospitality sector and already enjoyed the same lenient self-regulation trajectory as bars and cafés.

The smoking ban for workplaces and public transport came into force on 1 January 2004. The list of exceptions - the outcome of negotiations with civil society and pressure from parliament-was long: the hospitality sector (including theatres and music venues), tobacco specialty shops, amusement arcades, international trains, dedicated smoking rooms, private rooms in nursing homes and homes for the elderly, and penitentiary facilities. Hotels could reserve some of their rooms for smokers. Mental health institutions, old people's homes and institutions for the disabled were granted leeway so that smoking could be permitted in parts of the communal rooms, canteens, and waiting rooms. Dutch Railroads created smoking sections on train platforms to accommodate smoking travellers.

The implementation of the smoking ban was accompanied by a tax increase on February 2004 of $€ 0.55$ (including value-added tax [VAT]) per pack of cigarettes, a $14 \%$ increase. The tobacco manufacturers took this opportunity to also increase the price by $€ 0.25$, so that smokers were confronted with an effective increase of about $€ 0.80$. This undoubtedly encouraged the large number of quitters seen in 2004. 
The Ministry of Health worked closely with STIVORO to make the most out of the introduction of the ban. One of STIVORO's smoking cessation specialists was seconded to the ministry to strengthen the collaboration between the two organisations. There was a long period of preparation, during which employers and employees were kept informed: employers received practical advice (e.g., a "7-step implementation plan" was sent by STIVORO to all employers), a new website (Smoking and the Law) was developed to inform employees and employers about their new rights and obligations, employees were offered smoking cessation programmes, and media campaigns accompanied the ban. A large-scale campaign ("The Netherlands starts quitting") to support smokers who wanted to quit around I January 2004 was run by STIVORO when the smoking ban came into force.

The efforts paid off. When the Netherlands went "smoke-free" in 2004 and it was no longer legal to light up in public transport and workplaces, there was a broad feeling of relief. To the surprise of many, there were very few problems. The ending of smoking in trains went smoothly, without noticeable disturbances, and journalists described it as a quiet revolution (Huisman, 2005). After one year around 70\% of companies had successfully implemented smoking restrictions (VWS, 2005) and 75\% of employers thought that the smoking ban was "fair" (VWA, 2005). Support among smokers for the idea that workers must not be bothered by tobacco smoke increased over the span of a year, from $56 \%$ before the ban to $79 \%$ after (VWS, 2005). A national survey showed that smokers became more concerned about their smoking, and more aware that passive smoking could be harmful to others (Willemsen, 2006). The mass media campaigns that accompanied the ban contributed to smoking becoming less socially acceptable (Van den Putte, Yzer, Ten Berg, \& Steeveld, 2005). In the following years acceptance of smoking at work, in restaurants or bars, and on terraces further decreased (Hummel, Willemsen, Monshouwer, De Vries, \& Nagelhout, 2016).

Despite the highly successful implementation of the smoking ban, problems remained with implementing the worksite ban in some sectors of society. One of the issues was the problem of smoking in health-care facilities where people lived permanently, such as psychiatric wards and homes for the elderly. These institutions had had to comply since 1990 with the Tobacco Act, but the Act lacked financial sanctions. This changed with the new, amended Tobacco Act, which made these facilities liable for fines when employees continued to work in smoke-filled rooms. This led to much unrest and media attention. Adherence to smoking bans in these types of home had dramatically worsened since the beginning of 2004 . At 
the start of 2005, parliament debated the issue with the minister, voicing concerns from the mental health sector and workers in homes for the elderly where lifelong smokers could no longer smoke in their private rooms, so that workers were subject to all kinds of practical problems involved in escorting patients to smoking rooms. ${ }^{84}$ The debate resulted in majority support for motions to-once again-consider ventilation as an alternative, to force mental health institutes to come up with a roadmap similar to the one in the hospitality sector as an alternative to a ban, and to insist that the KHN removes the goal of reducing the number of vending machines from their roadmap. ${ }^{85}$ This latter motion was the result of incessant lobbying by British American Tobacco (BAT). The government responded by granting a one-year extension during which institutions would not be fined.

Parliament had repeatedly asked for better support for smokers with quitting smoking, especially financial reimbursement for costly pharmacotherapy for smoking cessation. Despite positive advice from the College voor Zorgverzekeringen (Health Care Insurance Board) (CVZ) (Kroes \& Lock, 2003) and positive results from a pilot study in the province of Friesland commissioned by the government, which had shown that smokers who were reimbursed made more attempts at quitting and were more successful (Kaper, Wagena, \& Van Schaijck, 2003), Hoogervorst did not want to make effective smoking cessation support for smokers illegible for financial reimbursement through the national health insurance system. ${ }^{86}$ This was partly because of budgetary considerations (it would cost $€ 45$ million per year), but mainly because he felt that smokers were themselves responsible for quitting, and did not need to be compensated since they saved money when they quit smoking.

\section{The National Program of Tobacco Control (NPT) (2005-2010)}

Since the Netherlands had implemented a comprehensive Tobacco Act, an important political question became whether this is sufficient for the time being or is more needed? In December 2004 Health Minister Hoogervorst started a round of consultations. ${ }^{87}$ A total of 47 organisations from the tobacco industry network and the health network received invitations to comment on the way the government had tackled the tobacco problem so far, and to give suggestions for future steps. On 17 
June 2005, Hoogervorst sent an evaluation of the government's tobacco control policy to parliament. ${ }^{88}$ It presented data showing that about $70 \%$ of businesses had implemented measures to protect workers from tobacco smoke, and that most employers were positive about the new law and had had little trouble implementing the new rules (VWA, 2005). The ministry concluded that the new regulations in the revised Tobacco Act, in combination with the price increase and intensive campaigns, had been successful, and that smoking rates were finally going down after a long period of stagnation. ${ }^{89}$ However, various breaches of the advertising and promotion ban had occurred as the tobacco industry continued to find loopholes. The report ended with the remark that other countries had much lower smoking rates and such results should be attainable in the Netherlands as well. However, instead of presenting a new governmental tobacco policy agenda, Hoogervorst made new policy intentions contingent on the tobacco control efforts of civil society and in particular the efforts of the three charities: Cancer Society, Lung Foundation, and Heart Foundation.

On 15 June 2005, the directors of the three charities and Hoogervorst signed a statement that they would join forces to intensify tobacco control: the Nationaal Programma Tabaksontmoediging (National Program of Tobacco Control) (NPT) (VWS, 2006)..${ }^{90}$ STIVORO was appointed as the central coordinating organisation, responsible for implementing the programme. The government and the charities committed to a policy goal of $20 \%$ smokers in the population by 2010 , even more ambitious than the goal of $25 \%$ in 2007, formulated in Hoogervorst's prevention paper. The ambitious goal was taken over from the Nationaal Programma Kankerbestrijding (National Program to Combat Cancer) (NPK), a collaboration between the Ministry of Health and Dutch cancer control organisations that had also started in 2005 (Jongejan, Hummel, Roelants, Lugtenberg, \& Hoekstra, 2003). With the NPK programme, the government answered to calls from WHO and the European parliament to establish a national "comprehensive cancer control programme" geared towards optimisation of cancer control in the Netherlands.

Hoogervorst's decision to share responsibility for national tobacco control with non-governmental organisations must be seen against the backdrop of the cabinet's desire to reduce the role of the state, in line with the Balkenende II cabinet's intent to reinforce personal responsibility and sovereignty in civil society. Hoogervorst formally justified this by referring 
to a section in the text of WHO's 2003 Framework Convention on Tobacco Control (FCTC), in which the role of civil society is mentioned briefly ${ }^{91}$ :

The special contribution of non-governmental organisations and other members of civil society ... to tobacco control efforts nationally and internationally and the vital importance of their participation in national and international tobacco control efforts. (WHO, 2003)

The Dutch government hoped that the cancer, lung, and heart charities would contribute financially to the NPT programme. A five-year plan was to be developed "that contained collective and reinforcing efforts that would optimise the current tobacco control policy." Its main focus was smoking cessation, through how-to-quit campaigns and support for smokers, including patients and smokers from low socioeconomic groups. ${ }^{92}$ While the $20 \%$ goal was taken from the NPK programme, the list of concrete policy actions for the government was not. ${ }^{93}$ Instead, a number of optional measures were listed that were "possible" or "conceivable," including increasing the price of tobacco, having pictorial health warnings on packs, developing mass media smoking cessation campaigns, increasing the age for tobacco sale to 18, enforcing smoking bans in the Horeca (the hotel, restaurant and café industry), and restricting tobacco sales to specialty shops (STIVORO, 2005).

In 2006, Hoogervorst announced an intention to put graphic health warnings on cigarette packs through an adaptation of the Tobacco Act. ${ }^{94}$ In addition, the old idea to restrict the sale of tobacco to specialty shops (Socialist Party member Jan Marijnissen's motion from 1996) was raised again. As a first step, Hoogervorst announced an increase in the legal age at which tobacco might be sold, from 16 to 18 , and the ending of mobile tobacco sales at festivals. ${ }^{95}$ These were policy intentions that required parliamentary approval. Parliament was informed on 18 May $2006^{96}$ and a first debate followed a few weeks later. ${ }^{97}$ The political reality was clear: the proposals had no chance. VVD, CDA, and LPF had a majority of 80 seats in parliament and were against. In June 2006, VVD parliamentarian Edith Schippers and Christian Democrat Siem Buijs tabled a motion condemning the government's prevention policy. ${ }^{98}$ In it they wrote that current disease prevention policy was mainly based on "more control and repression, such as bans, commandments, reduction of selling points, increases in taxation on specific drugs and other matters that threaten the health of 
the people in the eyes of the government." They demanded that the government base its policy on "positive proposals and less on repressive measures that increasingly affect people's private life." Their bill received support from a majority of the Parliament, ${ }^{99}$ signalling that there was no political support for tougher tobacco control.

From that moment the NPT programme was doomed. It was clear that the government had no political support for new policy measures, while the programme lacked a clear strategic plan and offered no ideas about how the ambitions and strengths of the four partners could best be accommodated and combined. The grim prospect of failing ambitions was confirmed when experts from the Rijksinstituut voor Volksgezondheid en Milien (National Institute for Public Health and the Environment) (RIVM) calculated the likely impact of the NPT measures and concluded that even with very optimistic estimates, the $20 \%$ target could not be reached without new policy measures (Vijgen et al., 2007). The target would only be obtainable when the government imposed yearly tobacco tax hikes (between 10\% and 20\%) and substantially increased the reach of efficacious smoking cessation support, and when both government and charities allocated substantial sums of money to mass media campaigns. It was clear that this would not happen. Around the same time, another report by the RIVM concluded that the Netherlands did not have a strict tobacco policy compared to other countries, and that smoking rates would not go down without further measures (Van der Wilk, Melse, Den Broeder, \& Achterberg, 2007). Policy steps that had been successful in other countries were recommended, such as a smoking ban in the hospitality sector, higher tobacco taxes, and better availability of smoking cessation services.

\section{Parallel Interests and the Fight Over Smoking in Bars}

In 2007 the fourth and last Balkenende cabinet was installed. This was a coalition of Christian Democrats, the Labour Party and the small Christian Union Party. The Minister of Health was Ab Klink (CDA), a liberal Christian Democrat pur sang and an influential party ideologist, having worked for many years at the scientific bureau of the CDA (between 1984 and 1992 as scientific staff member and from 1999 to 2007 as director). He re-introduced the idea of parallel interests as the leading concept for a prevention policy (Klink, 2007; VWS, 2007). This meant that such a policy was to be developed in concordance with the interests of societal 
organisations, including businesses and manufacturers, seeing "health as a justified interest in close connection with other justified interests," including those that were economic and social (VWS, 2007). The downside of this principle was that Klink de facto opened the door for tobacco industry lobbyists - and was far more receptive to industry contacts than previous ministers (see Chap. 8 for a detailed account of industry influence).

In 2007, the Netherlands was falling more and more behind other countries in Europe, as far as a policy to restrict smoking in pubs and bars was concerned. Seventeen countries had some kind of ban installed, including Germany (three states) and Belgium (albeit restricted to bars that serve food). ${ }^{100}$ In February 2007, at his first public appearance a few days before the first cabinet meeting, Minister Ab Klink (CDA) surprised everyone by proclaiming that the hospitality sector must become smoke free within a year. This was not in line with the coalition agreement, which had 2011 as the final date (the end of the cabinet period), while former Minister Hoogervorst had agreed with the sector that the period of selfregulation would last until 2009. Klink saw injustice in the fact that workers in this particular sector were not yet protected against tobacco smoke while workers in others sectors were. His proclamation was headline news, framed in newspapers as revealing his "true nature." Klink was depicted in the media as a patronising Christian moral crusader, an image he detested since he regarded himself as a dyed-in-the-wool liberal. He was also an occasional smoker of cigars himself. However, he kept his promise under pressure from a strong health lobby, and in June 2007 the cabinet announced that it wished to make the sector smoke-free within 12 months. ${ }^{101}$ The sports canteens and coffee shops, which also were still self-regulated, would be covered by the ban.

In the following months Klink set out to get approval from parliament. Between March and July the ministry organised consultation talks with representatives from the tobacco industry network, the hospitality sector, employer and employee organisations, the sports sector, and health organisations. ${ }^{102}$ Parliament further requested a written consultation round, which was organised in September. While the health organisations unanimously applauded the ban, the industry-related network of organisations raised concerns, most of which were rebutted by the ministry; however, some resulted in a weakening of the ban, such as a more lenient definition of a smoking section as a room "specifically" dedicated to smoking instead of "exclusively" dedicated to smoking. This opened the possibility of having attractive smoking sections in pubs, receiving the same services as non- 
smoking sections. The only difference was that personnel could not serve drinks and food at a table. ${ }^{103}$

Parliamentarians from different parties attempted to soften the ban. For example, VVD parliamentarian Edith Schippers tabled (unsuccessful) motions to allow bar owners to eliminate tobacco smoke through ventilation techniques, and to exempt small pubs and bars with no personnel. ${ }^{104}$ D66 and the Green-Left party drafted unsuccessful motions to exempt coffee shops from the ban. ${ }^{105}$ In July 2008 , the smoking ban was implemented in the hospitality sector, accompanied by a tax increase of $€ 0.29$ per pack of cigarettes, which translated to a consumer price increase of $€ 0.35$ per pack (including a price increase by the industry).

The Dutch bar smoking ban was one of the friendliest for smokers in Europe. Smoking was still allowed in designated areas with closed doors where personnel did not serve, and on covered terraces as long as one side was open. Smokers were not fined for non-compliance, only the bar owner. The ban was accompanied by a government-run mass media campaign that failed to explain the rationale for the ban. The campaign merely reinforced the image of pitiful smokers who were no longer welcome in cafés, and fanned the flames of discontent among bar owners and smokers' right groups. When the campaign was evaluated, it turned out that the proportion of people who were positive about a smoking ban in bars and restaurants (only $51 \%$ of the public) had not increased. ${ }^{106}$ Despite its inept implementation, compliance to the ban was high at first, despite the low level of fines: first a warning, then $€ 300$ for the first violation, which was doubled for each repeated offence up to $€ 2400$. In the first three months, the Netherlands Food and Consumer Product Safety Authority (NVWA) undertook 7264 inspections and found that $94 \%$ of the hospitality sector complied. ${ }^{107}$ This proportion was lower in pubs and bars, but was still $74 \%$, with $15 \%$ having a smoking section.

With support and legal advice from the tobacco industry, small pubs began to deliberately provoke the government by openly showing disobedience (Baltesen \& Rosenberg, 2009; Gonzalez \& Glantz, 2013). The NVWA started to impose fines from October 2008 onwards and the public prosecutor began criminal prosecution for obstinate offenders. In two months 821 fines were imposed. ${ }^{108}$ Tougher inspections, often accompanied by police officers, resulted in emotional responses from the smoking clientele of a small number of pubs. Some collected money from regular consumers to help pay fines. Newspapers ran headlines such as "Klink declares war on smokers pubs." The hospitality industry was quick to generate reports suggesting that the smoking ban had damaged the food and 
drink sector, which, it claimed, had suffered serious revenue declines and bankruptcies, leading to a series of parliamentary questions. ${ }^{109}$

In response to the pressure, parliamentarians from all parties declared themselves willing to explore pragmatic solutions to accommodate pub owners' concerns. Fleur Agema from the populist Partij voor de Vrijheid (Freedom Party) (PVV), the daughter of pub owners, called for several urgent debates on the matter, in which she attacked Minister Klink vehemently, demanding an end to the smoking ban for small pubs. Klink gave in to a request from the CDA to explore the possibility of using innovative air systems (such as curtains of air that prevented tobacco smoke from drifting from a smoking section to a non-smoking section) in bars, as an alternative to a full smoking ban. ${ }^{110}$ VVD and CDA, with support from most other parties, convinced Minister Klink to attempt to define exact norms for air quality in pubs that would be acceptable for public health. ${ }^{111}$ Until that moment, the government's stance was that there is no safe limit for exposure to second-hand smoke, in line with recommendations from the WHO and the RIVM. Chapter 8 discusses the industrial lobby for ventilation as an alternative to a smoking ban in more detail.

In the spring of 2009, successful legal procedures against the state by two small cafés (Victoria in Breda and De Kachel in Groningen) led to legal vagueness and uncertainty about whether the ban applied to small bars without personnel. Dutch courts considered the law discriminatory towards small bars without personnel on the grounds that the legislation was intended to protect employees from passive smoking, not visitors. This led to a new storm of media attention on the issue, and an escalation of the problem. Many pub owners reacted by replacing ashtrays on tables. In July 2009 Minister Klink responded by promising to rephrase the text of the Tobacco Act so that both employers and visitors would be protected. ${ }^{112}$ Pending these alterations, smoking in bars without personnel was condoned and no fines were imposed, and existing penalties were put on hold. In November 2009 the industry organised a public protest in The Hague to put more pressure on the government to withdraw the ban; VVD and PVV added fuel to the flames by calling for an urgency debate on the issue. ${ }^{113}$

In December 2009, Klink presented the results of an assessment of the remaining issues and problems with the smoking ban. ${ }^{114}$ The conclusion was reassuring: the ban was not responsible for reduced revenue for pubs and bars or for bankruptcies, as such effects could be explained by the long-term downward trend caused by the 2007-2008 global financial cri- 
sis, and financial compensation was therefore out of the question. Other potential problems, such as that small bars faced more technical obstacles in constructing smoking sections than did larger bars, and street disturbances when smokers went outside, remained within reasonable boundaries. About one-third of pubs had some sort of smoking section. ${ }^{115}$ In the same month, further results of studies commissioned by the Ministry of Health and sent to parliament ${ }^{116}$ showed that the smoking ban in bars and restaurants had improved the air quality (the concentration of fine dust particles), reduced exposure to second-hand smoke, had a beneficial effect on smoking cessation, and did not lead to more smoking in private homes (Dekker, Soethout, \& Tijsmans, 2009). The government appealed the court decision and in March 2010 the Dutch Supreme Court ruled that the legislation was not discriminatory and applied to all bars, including those without personnel. By that time, however, compliance had dropped to the point where a little over half of all bars and cafés had replaced their ashtrays (Intraval, 2010).

In line with his policy focus of approaching the tobacco problem in a positive manner, and his wish to not be accused of paternalism, Klink approved the introduction of financial reimbursement for smokers who need smoking cessation counselling. ${ }^{117}$ This would become available to smokers through the mandatory health-care insurance in the beginning of the next year (2011). This was a positive outcome, after a period of no less than 10 years of political hassle and many studies and advisory reports on this issue. The process had started in May 2001 with a motion by Labour and Socialist Parties (Rob Oudkerk and Agnes Kant) which requested the government to provide smokers with cessation support free of charge. ${ }^{118}$

\section{Failure of the NPT Programme}

Minister of Health Ab Klink put most of the NPT policy intentions initiated by Hoogervorst on ice. ${ }^{119} \mathrm{He}$ ignored the directors of the three health charities, who asked him to consider necessary measures such as pictorial health warnings on cigarette packs, increasing the age of sale to 18 years, and reducing the number of selling points (Rutgers, Hanselaar, Stam, \& Van Gennip, 2007). Klink formulated his tobacco control strategy in 2009 as follows: "if it comes to tobacco control, I want to focus mainly on positive incentives." ${ }^{120} \mathrm{He}$ distanced himself from the previous government's intent to implement graphic health warnings on cigarette packs (unattractive warnings were "bad taste"), ${ }^{121}$ said he did not want 
further regulation of tobacco sale outlets such as reducing their numbers or banning mobile sales of tobacco, and did not wish to pursue national regulations banning tobacco additives that increased attractiveness or addictiveness. ${ }^{122}$ There was hardly a protest from parliament, which was too preoccupied with the issue of smoking bans in small pubs.

In 2010, by the end of the five-year NPT period, smoking prevalence was still high $(27 \%)$ and had hardly decreased from when the NPT programme had started (28\% in 2006). Smoking among women had gone up, and youth smoking had not gone down. Despite clear messages from experts that the NPT goals were unrealistic without new tobacco control measures, the government under the leadership of Klink remained unwilling to take the necessary steps. The charities were disappointed and were, in turn, not prepared to contribute sufficient sums to campaigns, leading to a complete failure of the NPT programme and tremendous feelings of disappointment among the health organisations (Zeeman \& De Beer, 2012). STIVORO, which was responsible for execution of the programme, was scapegoated, and the three charities started to withdraw their financial support (further discussed in Chap. 9). Meanwhile, there was brief discussion within the government bureaucracy about starting a new five-year NPT programme, from 2011 to 2015 (Ministerie van Economische Zaken, 2010), but this was abruptly discarded when the Rutte cabinet came to power.

\section{Sudden Reversal of Tobacco Control Policy (2010-2012)}

On 20 February 2010, the Balkenende IV cabinet fell, over a dispute between the Labour Party and the Christian Democrats about continuing a military mission in the Afghan province of Uruzgan. The issue of smoking in pubs was declared controversial by the parliament, which meant that the resigning minister had to leave it to his successor to handle. In October 2010, the first Rutte cabinet took office. This was a minority cabinet formed by the VVD and the CDA, and had been made viable by support from the populist-libertarian PVV, which had enjoyed a tremendous election victory (from 9 to 24 seats). Support from the PVV put the Populist Party in a strong position to influence the new government's policy decisions, both through the coalition agreement and through parliament. Rutte's coalition agreement with the motto "freedom and responsibility" included few words on tobacco policy, but these few had far-reaching consequences. The coali- 
tion agreement included a firm commitment to ease the smoking ban by exempting bars without employees from the obligation to implement smoking restrictions. The criterion for a small bar was that it had less than 70 square metres of surface, modelled after the German smoking ban.

The main challenge for the new government was to deal with the aftermath of the economic crisis through a huge project to reduce government spending. The coalition agreement included large cuts to the Ministry of Health, including a $€ 50$ million reduction of spending on health education (Nagelhout \& Fong, 2011). The new minister of Health was Edith Schippers (VVD) who since 2003 had been responsible for health issues as a member of the VVD parliamentary faction. Tobacco control advocates had long regarded her as one of their toughest opponents: she was known as a fighter for free-market principles and a strong adversary of the "nanny state," had opposed virtually every proposal for governmental regulation in the field of tobacco, and had been successful in softening the impact of the Tobacco Act and in limiting smoking bans. Schippers now saw an opportunity to execute a conservative-liberal agenda and reduce the government's involvement with tobacco to a minimum. She knew she had full support from the PVV, whose leader Geert Wilders was a smoker himself and had been a defender of tobacco industry interests in the Balkenende I cabinet when he was still a member of the VVD. When Schippers was the VVD spokesperson on tobacco in the Balkenende II cabinet, Minister Hoogervorst (also VVD) had repeatedly debated with her over tobacco and lifestyle. At one point Schippers characterised Hoogervorst's policy as "lifestyle inquisition." 123 When Hoogervorst was no longer minister, he looked back and commented on Schippers: "Edith is against a nanny state, while I had come to the conclusion that strict measures had to be taken. That debate between the two of us was very harsh sometimes" (Niemantsverdriet, 2011).

Like Klink, Schippers politicised prevention policy by taking ideological values as a starting point. It did not come as a surprise that Schippers, in her maiden speech as minister in parliament on 28 October 2010, announced that there was going to be a radical change: "From my point of view, from my personal conviction, it is absolutely disastrous if the government forces people into a straitjacket by all sorts of regulations, do's and don'ts, restrictions, images with doom scenarios, patronising and pedantic messages." 124 Schippers formulated the new political stance towards prevention as follows: "I don't think the government is a happiness machine, nor is it a lifestyle master. It is very important for me to 
make a change of policy which does justice to the motto of this cabinet, which is freedom and responsibility."

During a debate in parliament the Socialist Party (SP) and Christian Union $(\mathrm{CU})$ noted that the proportion of smokers had stagnated and the government's aim to reduce smoking to $20 \%$ in 2010 had not been met. ${ }^{125}$ They tabled two motions: one demanding that the minister present an effective package of measures to combat smoking as part of her prevention policy document, which was due later that year, and one requesting that the government take tobacco prevention seriously and reduce the number of tobacco sale outlets. Schippers rejected both. A few weeks later she confirmed the government's intention to exempt small cafés from the smoking ban ${ }^{126}$; but enforcement was postponed immediately in anticipation of a revision of the applicable order-in-council. In July 2011 smoking was officially allowed in small bars. To support the new regulation, fines were doubled for those who did not comply with the law.

Soon after her appointment Schippers announced that she was going to cut subsidies to disease prevention institutes. In May 2011, Schippers' health nota was published (VWS, 2011). Tobacco control was no longer a priority. She announced a three-year phasing down of subsidies to STIVORO, while smoking prevention was to be handed over to the Trimbos Institute (the Netherlands Institute of Mental Health and Addiction). This echoed parliamentary questions raised by Schippers in 2004 criticising alleged wastage of subsidies by STIVORO, ${ }^{127}$ and again from 2008 questioning the necessity of the subsidies that STIVORO received and whether the government was financing its own political opposition. ${ }^{128}$ Reimbursement for smoking cessation support was to be discontinued in 2012. Mass media campaigns were described as paternalistic and completely discarded. These swift and dramatic shifts were an unprecedented reversal of tobacco control policy decisions, and met with indignation and astonishment both from Dutch health and medical advocacy groups (NKI-AVL, 2012) and from international tobacco control experts (Arnott et al., 2011). The Network for Accountability of Tobacco Transnationals nominated the Dutch government for a "Marlboro Man Award," a "less-than-prestigious price for a government that is furthering Big Tobacco's interests and putting profit over people." ${ }^{129}$ Ex-minister Hoogervorst commented: "Reversal of the smoking ban is a rear-guard action. The whole world is making its tobacco policy tougher, while the Netherlands is making its policy more lenient. I am a bit embarrassed" 
(Niemantsverdriet, 2011). Schippers' tough position led to a strong polarisation between the Ministry of Health and tobacco control groups, especially STIVORO. This was aggravated when public television broadcasted a documentary in October 2011 entitled "Minister of Tobacco," revealing contacts between the Dutch tobacco industry network and Schippers. ${ }^{130}$

\section{Normalisation of Relationships (2012-2017)}

In November 2012 the tension between government and health organisations over tobacco lessened when tobacco control became the task of State Secretary Martin van Rijn (Labour party) in the new Rutte-Ascher cabinet (a coalition between VVD and Labour Party). The Populist PVV party was no longer needed to support the government, and with its retreat from power there was less support for an extremely restrained tobacco control policy. Van Rijn normalised relationships between the ministry and health organisations by promising to follow the path of reason and by examining what could be done to strengthen tobacco control. Van Rijn had struck a deal with VVD and Schippers, who was still health minister, that no new tobacco regulatory measures would be taken in the next four years. Van Rijn moved cautiously, evaluating the effectiveness of a new measure before taking additional steps. He managed to retain this strategy until the end of the cabinet, arguing in parliament that he wanted policy measures that were enforceable, effective, based on science, consistent, and attracting sufficient societal support "while we constantly search for new methods to eliminate smoking." "131 In July 2014, Van Rijn sent a number of reports to the parliament, which examined new policy options such as restricting the number of selling points and point-of-sale restrictions, and promised to present a plan at the end of the year (Van Rijn, 2014).

In December 2013, the European parliament reached an agreement with the EU Council of Ministers about a new Tobacco Product Directive (TPD-2), which included pictorial health warnings covering $65 \%$ of the front and the back of tobacco packs, restrictions on the use of flavourings and dangerous additives in tobacco, and a ban on slim cigarettes. The new directive came into force on May 2014, and most provisions were implemented in the Netherlands by May 2016. Another policy measure that Van Rijn took did not follow his own initiative as well, but was the result of outside pressure: it had been decided that the age limit for drinking 
alcoholic beverages would rise from 16 to 18, to come into effect on 2014, and the parliament wanted a similar regulation for tobacco. After a parliamentary vote in October 2013, the legal age limit for selling tobacco was raised from 16 to 18, and went into effect in January 2014. Van Rijn further amended the Tobacco Act, so that small cafés were included again in the general smoking ban. This followed a successful legal action by CAN against the state that obliged the government to reconsider the exemption, and a successful motion from the Christian Union (CU) party that received majority backing ( 77 votes) in parliament. The motion requested the government to bring small cafés back under the smoking ban. ${ }^{132}$ This came into effect in October 2014. In early 2017, parliament adopted an amendment to the Tobacco Act that included a ban on the display of tobacco products at point of sale, as part of the ban on advertising.

\section{Conclusions}

The main events of the narrative of how government and parliament shaped Dutch tobacco control policy are summarised in Box 2.2. The ambitions of the 1970s came to a virtual standstill in the 1990s, stuck in the political quagmire of the Dutch "polder." 133 Subsequent governments were reluctant to take decisive steps, sensing that this would meet with resistance from the tobacco industry, the business community, and the parliament, and they adopted a long-term approach of small steps. Tobacco policy was strengthened several times, often after long periods of selfregulation by the industry that was preferred over legally binding measures.

Box 2.2 Major tobacco control policy events in the Netherlands

\begin{tabular}{|c|c|}
\hline Year & Event \\
\hline 1957 & $\begin{array}{l}\text { - Dutch Health Council advisory report Smoking and bealth confirms } \\
\text { association between smoking and lung cancer }\end{array}$ \\
\hline 1965 & - Start of "gentlemen's agreement" among tobacco manufacturers \\
\hline 1974 & $\begin{array}{l}\text { - Decision to create a national coordinating organisation for tobacco } \\
\text { control, resulting in the foundation of STIVORO }\end{array}$ \\
\hline 1975 & $\begin{array}{l}\text { - Dutch Health Council report Measures to reduce smoking proposes a } \\
\text { comprehensive tobacco policy }\end{array}$ \\
\hline 1976 & - Advisory report by Meulblok Committee on tobacco advertising \\
\hline
\end{tabular}




\begin{tabular}{|c|c|}
\hline Year & Event \\
\hline 1977 & - State Secretary Hendriks presents the Tobacco Memorandum \\
\hline 1981 & - STIVORO starts educational campaigns \\
\hline 1980 & - Ban on tobacco advertisements on radio and television \\
\hline \multirow[t]{2}{*}{1981} & - Law on health warnings adopted \\
\hline & $\begin{array}{l}\text { - Industry-friendly advisory report from the second interdepartmental } \\
\text { committee (ICBT) presented }\end{array}$ \\
\hline \multirow[t]{2}{*}{1982} & - Health warnings on cigarette packs ("Smoking threatens health") \\
\hline & - New advertising code of conduct initiated by industry \\
\hline 1984 & $\begin{array}{l}\text { - Draft Tobacco Act (smoking ban in public places) presented to } \\
\text { parliament }\end{array}$ \\
\hline \multirow[t]{2}{*}{1988} & - New advertising code of conduct (Reclame Code) \\
\hline & - Tobacco Act adopted (smoking banned in public places) \\
\hline \multirow[t]{2}{*}{1990} & - First Health Council report on passive smoking \\
\hline & - Tobacco Act implemented \\
\hline \multirow[t]{2}{*}{1995} & - “Healthy and Well” policy document (Minister Borst) \\
\hline & - Advertising ban for billboards (self-regulation) \\
\hline \multirow[t]{2}{*}{1996} & - Advertising ban in cinemas (self-regulation) \\
\hline & - “Nota Tabaksontmoedigingsbeleid" (Minister Borst) \\
\hline 1997 & - The Netherlands supports the EU advertising ban \\
\hline 1998 & - NSPH report advised on comprehensive national tobacco policy \\
\hline \multirow[t]{3}{*}{2002} & $\begin{array}{l}\text { Amendment to Tobacco Act adopted: smoke-free workplaces (with } \\
\text { exception for hospitality sector), advertising and promotion ban, age } \\
\text { limit for sale of tobacco set at } 16 \text { years }\end{array}$ \\
\hline & - Self-regulation for hospitality sector until 2009 \\
\hline & $\begin{array}{l}\text { - Large EU text health warnings on cigarette packs (30\% front, } 40 \% \\
\text { back) }\end{array}$ \\
\hline 2003 & - Second Health Council report on passive smoking \\
\hline 2004 & - Smoking ban in workplaces implemented \\
\hline 2005 & - Netherlands ratifies FCTC \\
\hline 2006 & $\begin{array}{l}\text { - Start of the National Program of Tobacco Control (NPT) } \\
2006-2010\end{array}$ \\
\hline 2007 & - Mister Klink announces to make hospitality industry smoke-free \\
\hline 2008 & - Smoking ban extended to hospitality sector \\
\hline 2009 & $\begin{array}{l}\text { - Temporary suspension of smoking ban in small bars without } \\
\text { personnel }\end{array}$ \\
\hline 2010 & $\begin{array}{l}\text { - Suspension overruled by supreme court (smoking ban again in place), } \\
\text { then suspended again }\end{array}$ \\
\hline \multirow[t]{3}{*}{2011} & - Smoking cessation treatment reimbursed \\
\hline & - Smoking again allowed in small bars with no personnel \\
\hline & $\begin{array}{l}\text { - Minister Schippers stops subsidy to STIVORO while transferring } \\
\text { tobacco education to the Trimbos Institute }\end{array}$ \\
\hline 2012 & - Smoking cessation treatment no longer reimbursed \\
\hline
\end{tabular}




\begin{tabular}{|c|c|}
\hline Year & Event \\
\hline 2014 & $\begin{array}{l}\text { - Ban on tobacco sale extended to all under } 18 \text { years } \\
\text { - Smoking ban extended to all bars, including small bars with no } \\
\text { personnel }\end{array}$ \\
\hline 2016 & $\begin{array}{l}\text { - EU Tobacco Product Directive II implemented: pictorial warnings } \\
\text { on cigarette packs }\end{array}$ \\
\hline 2017 & $\begin{array}{l}\text { - Ban on the display of tobacco products at point of sale adopted by } \\
\text { parliament }\end{array}$ \\
\hline
\end{tabular}

The 1988 Tobacco Act did not contain measures strong enough to affect smoking rates, and until the end of the 1990s health considerations were subordinate to economic interests. This changed when Health Minister Borst amended the Tobacco Act in 2002 and brought it up to international standards. None of Borst's successors has taken comprehensive tobacco control initiatives remotely similar to hers.

The Dutch governments' approach to tobacco control can be characterised as reactive and cautious, resulting in incremental change instead of radical steps. With the exception of Health Minister Borst (1994-2002), none of the state secretaries or health ministers who were responsible for tobacco control took much interest in the topic; none showed strong leadership. Official documents did not outline bold ambitions; nor did they testify to a vision of tobacco control that might inspire the nation. The bureaucracy seemed to react to incidents rather than initiate them, and to feel most comfortable with a technical, non-visionary approach. Even Minister Borst realised that she could not make great strides. During a debate in the senate in 2002, she lamented: "How does one handle things in such a way that individual freedom of adults is respected while at the same time trying to reduce the harm [of smoking]? It is a struggle. That is why we take it one step at a time and do not try to make some sort of enormous victory in one smash." 134

One important observation is that Dutch politicians and government officials consistently tried the least controversial option first and gradually progressed to more stringent measures. Policies often metamorphose in such a way. According to John (2012, p. 20), policy change is often limited to "minor variations in a pattern of continuity." These have been called first, second, and third order policy changes (Hall, 1993). A first 
order change is when a policy remains the same but is adjusted to new circumstances and new experiences. In the case of the Netherlands, smoking bans were broadened from public places to workplaces and eventually to the hospitality sector. Another first order change concerned the age limit for the sale of tobacco, which increased from 16 to 18 years.

Second order change is when the instrument of policy is altered while the overall goals remain the same. The oldest example was the realisation that education alone would not solve the problem, and that regulation of the product and how it was sold and marketed were necessary as well. Another second order change occurred when self-imposed advertising restrictions were broadened several times and eventually replaced by an advertising and promotion ban.

A third order change is characterised by a more radical shift in the goal of the policy. This is more politically or ideologically inspired than based on the appearance of new facts about what works or experiences with failed policy. The change from regarding tobacco use as an economic benefit to seeing it as a public health threat can be regarded as a radical shift (Studlar \& Cairney, 2014). In the Netherlands this process started in the 1960s with the growing recognition of the seriousness of the health problems of tobacco, and eventually evolved into the current dominant public health perspective. The key alteration of the status quo occurred between 2002 and 2004 when the Tobacco Act was amended and Minister Borst successfully took tobacco policy out of the sphere of influence of the trade ministry and under the control of the Ministry of Health, resulting in tobacco control measures that had a huge impact on society. However, this was not a guarantee of consistent strong tobacco control in subsequent years. Later health ministers assigned such low priority to tobacco control that it stagnated under Minister Klink (2007-2010) and even temporarily reversed under Minister Schippers (2010-2012).

In the next chapter, a comparison will be made between the trajectory of tobacco control in the Netherlands and those of other European countries. Subsequent chapters explore in more detail some of the explanatory factors that have already been briefly alluded to in the current chapter: changes in governance (decentralisation, power shift to Brussels), institutional changes (more control ceded to the Ministry of Health at the expense of the Ministry of Economic Affairs), the importance of the judiciary, the role of ideology (neo-liberalism and small government), rules of the game (polderen), and the influence of the anti- and pro-tobacco control lobbies. 


\section{Notes}

1. Appendix Proceedings I, 1963-1964, nr. 14.

2. In 1971 this code of conduct was weakened by agreeing that "it is not against the rules if information is given in a positive way, either in word or illustration, about the way of smoking and how a maximum of smoking satisfaction can be derived" (Van Vliet, 1971).

3. Philip Morris drafted mission and action plans for the Stichting Reclame Code (Advertising Code Foundation) (SRC) so that it would have maximum additional value (Philip Morris, 1996).

4. Proceedings II, 1969-1970, Annex 1074.

5. Proceedings II, 1971-1972, Annex 707.

6. Proceedings I, 1970-1971, Annex 40.

7. Parliamentary Papers II, 1976-1977, 14,360, nr. 1.

8. It also referred to the WHO report Smoking and Its Effects on Health (WHO, 1975).

9. Parliamentary Papers II, 1976-1977, 14,360, nr. 2.

10. These were regulations to limit the sale of tobacco to specialty shops (including a ban on vending machines) and to use tobacco taxation as a means to improve health.

11. Parliamentary Papers II, 56ste meeting, l March 1979, p. 3781.

12. Parliamentary Papers II, 1982-1983, 17,600, nr. 36.

13. Parliamentary Papers II, 1977-1978, 14,800 XVII, nr. 34.

14. A ban on advertising through television and radio was effectuated in 1980 by an order-in-council to the existing Broadcasting Act (Ministry of Culture, Recreation and Welfare).

15. Parliamentary Papers II, 56ste meeting, l March 1979, p. 3780.

16. Parliamentary Papers II, 1978-1979, 15,426, nr. 12.

17. Proceedings II, 29 October 1980.

18. Parliamentary Papers II, 1979-1980, 15800 XVII, nr. 37.

19. Parliamentary Papers II, 1980-1981, 16400 XVII, nr. 32.

20. Proceedings II, 1980-1981, 15,426, nr. 24.

21. Parliamentary Papers II, 1981-1982, 17,100 Chapter XIII, nr. 149.

22. Parliamentary Papers II, 1984-1985, 18,749, nrs. 1-3.

23. Parliamentary Papers II, 1984-1985, 18,749, nr. 3.

24. Parliamentary Papers II, 1984-1985, 18,749, nr. 3.

25. Proceedings II, $48^{\mathrm{c}}$ meeting, 11 February 1985 , pp. 48-46.

26. Parliamentary Papers II, 1986-1987, 18,749, nr. 14; Parliamentary Papers II, 1986-1987, 18,749, nr. 35.

27. Interview, on 24 August 2016.

28. Proceedings II, I July $1987,94-4839$.

29. Parliamentary Papers, 1987-1988, 20,259, nrs. 1-2. 
30. Proceedings I, $17^{\mathrm{e}}$ meeting, 8 March 1988, pp. 17-562.

31. 200 million guilders in 1996 is comparable to $€ 300$ million (current value); Parliamentary Papers II, 1998-1999, 26472, nr. 3.

32. Promotion of tobacco products on TV and radio was banned on 22 February 1980, based on Article 50.2 of the Broadcasting Act (ICBT, 1981).

33. Proceedings $\mathrm{I}, 17^{\mathrm{e}}$ meeting, 8 March 1988.

34. Proceedings II, 1991-1992, 22,300 XVI, nr. 7.

35. Parliamentary Papers II, 1992-1993, 22,684, nr. 4. p. 34.

36. Parliamentary Papers II, 1991-1992, 22300 XVI, nr. 36, pp. 9-10.

37. Parliamentary Papers II, 1991-1992, 22300 XVI, 7, p. 13.

38. The STAR, founded in 1945, is where employers and employees negotiate social-economic topics such as wages, pensions, employability and workers safety. It comprises the main employer representatives organisations (such as VNO-NCW) and the main employee representatives organisations. It represents the cornerstone of Dutch "polderen."

39. Proceedings II, 22 December 1993, 41, 3246-3247.

40. Proceedings II, 1993-1994, 23400 XVI, 78, p. 5.

41. This changed in the second cabinet Kok, when Annemarie Jorritsma (VVD) became Minister of Economic Affairs.

42. Parliamentary Papers II, 1994-1995, 24,126, nr. 2.

43. Parliamentary Papers II, 1995-1996, 24,126, nr. 7, p. 5.

44. Proceedings II, 1995-1996, 24,126, nr. 10.

45. 100,000 guilders in 1995 is comparable to about $€ 67,000$ in 2017.

46. Parliamentary Papers II, 1995-1996, 24743, nr. 1.

47. In Dutch: "Roken, dood en doodzonde."

48. Parliamentary Papers II, 1996-1997, 24,743, nr. 2.

49. Proceedings II, 1997-1998, 21, 501-519, nr. 29.

50. Proceedings II, 1996-1997, 18, 1266-1268.

51. Parliamentary Papers II, 1996-1997, 24,743, nr. 19.

52. Proceedings II, 29 October 1996, 18-1266.

53. Proceedings II, 1998-1999, 26,472, nr. 3.

54. Proceedings II, 1998-1999, 26,472, nr. 3, pp. 12-13.

55. Parliamentary Papers II, 1984-1985, 19,749, nr. 3.

56. Parliamentary Papers II, 1999-2000, 26,472, nr. 6, p. 45.

57. Parliamentary Papers II, 1999-2000, 26,472, nr. 6.

58. Parliamentary Papers II, 1999-2000, 26,472, nr. 6, p. 6.

59. Parliamentary Papers II, 1998-1999, 26,472, nr. 4.

60. Parliamentary Papers II, 1999-2000, 26,472, nr. 6, p. 24.

61. Parliamentary Papers II, 2000-2001, 26,472, nr. 8.

62. Proceedings II, 31 May 2001, 82, 5175-5239.

63. Parliamentary Papers II, 2000-2001, 26,472, nr. 12. 
64. Parliamentary Papers II, 2000-2001, 26,472, nr. 13.

65. http://www.trouw.nl/tr/nl/5009/Archief/article/detail/2496082/ 2001/03/29/Borst-wil-betere-positie-niet-roker.dhtml

66. Proceedings II, 6 June 2001, 83, 5258-5260.

67. Proceedings I, 2001-2002, 26,472, nr. 59 .

68. Parliamentary Papers II, 1999-2000, 26,472, nr. 6.

69. Proceedings II, 31 May 2001, 82, 5175-5239.

70. Parliamentary Papers I, 2001-2002, 26,472, nr. 59a.

71. This is equivalent to $€ 18$ million in 2015 .

72. Proceedings I, Tabakswet, 26 March 2002, 24-1236.

73. Interview, on 22 March 2016.

74. Proceedings II, 26 September 2002, 6, 343-356.

75. Proceedings I, 17 December 2002, 13, 406-417.

76. Parliamentary Papers I, 2002-2003, 28,401, nr. 60c.

77. Proceedings II, 2002-2003, 28,600 XVI, nr. 146.

78. Proceedings II, 2002-2003, 28,600 XVI, nr. 154.

79. Proceedings II, 2003-2004, 29,200 XVI, nr. 158.

80. Proceedings, 2003-2004, Annex 619.

81. Proceedings II, 25 November 2003, 28, 1963-1967.

82. Proceedings II, 2 December 2003, 31, 2176.

83. Ibid.

84. Proceedings II, 2004-2005, 29,800 XVI, nr. 98.

85. Proceedings II, l February 2005, 44-2845.

86. Proceedings II, 2004-2005, 29,800 XVI, nr. 136, p. 6.

87. Parliamentary Papers II, 2004-2005, 22,894 en 29,800 XVI, nr. 55.

88. Parliamentary Papers II, 2004-2005, 22,894, nr. 61.

89. Parliamentary Papers II, 2004-2005, 22,894, nr. 61.

90. Parliamentary Papers II, 2005-2006, 22,894, nr. 83.

91. Proceedings II, 2004-2005, 22,894, nr. 61.

92. Parliamentary Papers II, 2006-2007, 22,894, nr. 114.

93. The NPK programme listed a number of actions: to classify tobacco smoke as a carcinogenic substance, to recognise that smoking is an addictive disease, to provide financial reimbursement for smoking cessation support, to introduce a full smoking ban in hospitality establishments as soon as possible, and to increase tobacco tax levels by at least $€ 50$ cents above inflation every two years (Jongejan et al., 2003).

94. Parliamentary Papers II, 2005-2006, 22,894, nr. 78.

95. Parliamentary Papers II, 2005-2006, 22,894, nr. 83.

96. Parliamentary Papers II, 2005-2006, 22,894, nr. 86.

97. Parliamentary Papers II, 2005-2006, 22,894, nr. 104.

98. Proceedings II, 2005-2006, 22,894, nr. 94. 
99. The bill was supported by D66, the Groep Wilders, de VVD, CDA, LPF en the Groep Nawijn; voting was on 27 June 2006.

100. Parliamentary Papers II, 2006-2007, 31, 200-XVI-7-bl.

101. Parliamentary Papers II, 2006-2007, 30,800 XVI, nr. 149.

102. Parliamentary Papers II, 2007-2008, 31,200 XVI, nr. 8.

103. Parliamentary Papers II, 2007-2008, 31,200 XVI, nr. 8.

104. Proceedings II, 5 July $2007,90-5101$.

105. Proceedings II, 18 October 2007, 15-1021.

106. Parliamentary Papers II, 2009-2010, 32011, nr. 5.

107. Parliamentary Papers II, 2008-2009, 22894, nr. 206.

108. Parliamentary Papers II, 2008-2009, 22,894, nr. 206.

109. Proceedings II, 2008-2009, Annexes 570, 1648, 1867, 2267, and 3169.

110. Proceedings II, 2008-2009, 22,894, nr. 216; Parliamentary Papers II, 2008-2009, 32,011, nr. 1.

111. Proceedings II, 2 April 2009, 72-5691.

112. Parliamentary Papers II, 2008-2009, 32,011, nr. 1.

113. Proceedings II, 2008-2009, 22,894, nr. 207.

114. Parliamentary Papers II, 2008-2009, 22,894, nr. 206.

115. Parliamentary Papers II, 2008-2009, 22,894, nr. 212.

116. Parliamentary Papers II, 2009-2010, 32,011, nr. 3.

117. Parliamentary Papers II, 2009-2010, 22,894, nr. 280.

118. Proceedings II, Tabakswet 31 mei 2001, TK 82-5220.

119. Parliamentary Papers II, 22894, nr. 154.

120. Parliamentary Papers II, 2008-2009, 22,894, nr. 226.

121. Parliamentary Papers II, 22,894, nr. 167.

122. Parliamentary Papers II, 2007-2008, 22,894, nr. 153.

123. Proceedings II, 2003-2004, 29,200 XVI, nr. 158.

124. Proceedings II, TK 15, 28 October 2010.

125. Proceedings II, TK 15, 28 October 2010.

126. Parliamentary Papers II, 2010-2011, 22,894, nr. 289.

127. Proceedings II, 2003-2004, Parliamentary Questions 2030408200.

128. Proceedings II, 2007-2008, 22,894, nr. 167.

129. https://www.stopcorporateabuse.org/press-release/netherlandsnominated-\%E2\%80\%9Cmarlboro-man-award\%E2\%80\%9D

130. In the investigative journalistic series "Zembla."

131. Proceedings II, 2 October 2013, TK 8, 8-6-1.

132. Parliamentary Papers II, 2012-2013, 33,400 XVI, nr. 78.

133. "Polder" refers to the Dutch version of consensus-based policymaking (see Chap. 5 ).

134. Proceedings I, 26 March 2002. 


\section{REFERENCES}

Algemene Rekenkamer. (1982). Verslag van een onderzoek naar de gesubsidieerde activiteiten verband houdend met het tegengaan van het roken en daarmee samenhangende aangelegenheden. Truth Tobacco Industry Documents, Bates No. JB2303. Retrieved from https://industrydocuments.library.ucsf.edu/ tobacco/docs/\#id=kpdp0219

Arnott, D., Berteletti, F., Britton, J., Cardone, A., Clancy, L., Craig, L., ... Willemsen, M. C. (2011). Can the Dutch Government really be abandoning smokers to their fate? The Lancet, 379, 121-122. https://doi.org/10.1016/ S0140-6736(11)61855-2

ASH. (2013). Key dates in the history of anti-tobacco campaigning. Retrieved August 29, 2014, from http://www.ash.org.uk/files/documents/ASH_741.pdf

Baltesen, F., \& Rosenberg, E. (2009, June 22). Big tobacco pays Dutch opposition to smoking ban. NRC Handelsblad. Retrieved from http://vorige.nrc.nl/ international/article2278646.ece/Big_tobacco_pays_Dutch_opposition_ to_smoking_ban

Beernink, J. F., \& Plokker, J. H. (1975). Maatregelen tot beperking van het roken. Advies van de Gezondheidsraad. Verslagen, Adviezen, Rapporten (Vol. 23). Leidschendam: Ministerie van Volksgezondheid en Milieuhygiëne.

Berridge, V., \& Loughlin, K. (2005). Smoking and the new health education in Britain 1950s-1970s. American Journal of Public Health, 95, 956-964. https://doi.org/10.2105/AJPH.2004.037887

Colby, F. G. (1979). Summary of the PR program of the Dutch Cigarette Manufactures Association. RJ Reynolds Records Collection, Bates No. 500877429-500877431. Retrieved from https://industrydocuments.library. ucsf.edu/tobacco/docs/\#id=jrpj0096

De Jong, A. (2000). Complete prohibition on smoking in the workplace. British American Tobacco Records, Bates No. 322075711-322075712. Retrieved from http://legacy.library.ucsf.edu/tid/llp14a99

De Landsadvocaat. (1995). Verbod tabaksreclame. Dutch Tobacco Industry Collection, Bates No. JB1037. Retrieved from https://www.industrydocumentslibrary.ucsf.edu/tobacco/docs/gtcp0219

Dekker, H., Soethout, J., \& Tijsmans, N. (2009). Even uitblazen. Eén jaar rookvrije horeca. Amsterdam: Regioplan Beleidsonderzoek.

Department of Health. (2004). Choosing health: Making healthy choices easier. London: UK Department of Health.

Doll, R., \& Hill, A. B. (1950). Smoking and carcinoma of the lung: Preliminary report. British Medical Journal, 2, 739-748.

Dresscher, I., Elzinga, A., \& Koldenhof, E. (1991). Evaluatie tabakswet en zelfregulering tabaksreclame. Zoetermeer: Research voor Beleid. 
Gadourek, I. (1963). Riskante gewoonten en zorg voor eigen welzijn. Groningen: J.B. Wolters.

Gezondheidsraad. (1990). Passief roken: Beoordeling van de schadelijkheid van omgevingstabaksrook voor de gezondheid. Den Haag: Gezondheidsraad.

Gezondheidsraad. (2003). Volksgezondheidsschade door passief roken. Den Haag: Gezondheidsraad.

Gonzalez, M., \& Glantz, S. A. (2013). Failure of policy regarding smoke-free bars in the Netherlands. European Journal of Public Health, 23(1), 139-145. https://doi.org/10.1093/eurpub/ckr173

Hall, P. (1993). Policy paradigms, social learning, and the state: The case of economic policymaking in Britain. Comparative Politics, 25, 257-296.

Huisman, C. (2005). Uit de walm. Volkskrant. Retrieved from http://www.volkskrant.nl/archief/uit-de-walm a643849/

Hummel, K., Willemsen, M. C., Monshouwer, K., De Vries, H., \& Nagelhout, G. E. (2016). Social acceptance of smoking restrictions during 10 years of policy implementation, reversal, and reenactment in the Netherlands: Findings from a national population survey. Nicotine \& Tobacco Research, 19, 1-8. https://doi.org/10.1093/ntr/ntw169

ICBT. (1981). Advies inzake maatregelen ter beperking van het tabaksgebruik. Den Haag: Interdepartementale Commissie Beperking Tabaksgebruik (ICBT), Ministerie van Volksgezondheid en Milieu.

Interdepartementale Commissie Tabaksreclame. (1972a). Verslag van een Hearing op 24 januari 1972 over het onderwerp reklame voor tabaksprodukten, gehouden door de Interdepartamentale Commissie. Dutch Tobacco Industry Collection, Bates No. JB1936. Retrieved from https://industrydocuments. library.ucsf.edu/tobacco/docs/mhbp0219

Interdepartementale Commissie Tabaksreclame. (1972b). Verslag vergadering Interdepartementale Werkgroep Tabaksreclame 13 juli 1972. Dutch Tobacco Industry Collection, Bates No. JB1858. Retrieved from https://www.industrydocumentslibrary.ucsf.edu/tobacco/docs/hkgp0219

Intraval. (2010). Inventarisatie naleefnivean rookvrije horeca najaar 2010. Groningen: Intraval.

John, P. (2012). Analyzing public policy (2nd ed.). London: Routledge.

Jongejan, B. A. J., Hummel, H., Roelants, H. J., Lugtenberg, G., \& Hoekstra, G. A. (2003). National Cancer Control Programme. Part I-NPK vision and summary 2005-2010. Den Haag: NPK Steering Group.

Kalis, A. W. (2000). Tabaksaccijns. Dutch Tobacco Industry Collection, Bates No. JB2028. Retrieved from https://www.industrydocumentslibrary.ucsf.edu/ tobacco/docs/lpfp0219

Kaper, J., Wagena, E. J., \& Van Schaijck, O. (2003). Het effect van het vergoeden van ondersteuning voor stoppen met roken: Resultaten van een gerandomiseerd experiment. Maastricht: Universiteit van Maastricht. 
Klink, A. (2007). Kaderbrief 2007-2011 visie op gezondheid en preventie. Den Haag: Ministry of Health.

Kroes, M. E., \& Lock, A. J. J. (2003). Stoppen met roken ondersteuning: Zeker weten! Diemen: College voor Zorgverzekeringen (CVZ).

Meulblok, J. (1975). Advies inzake maatregelen tot beperking van de reclame voor sigaretten en shag en tot het aanbrengen van aanduidingen op de verpakkingen van sigaretten en shag. Dutch Tobacco Industry Collection, Bates No. JB2105. Retrieved from https://www.industrydocumentslibrary.ucsf.edu/tobacco/ docs/ztbp0219

Ministerie van Economische Zaken. (1991). Nota Mondeling Overleg 17 oktober 1991 met vaste Commissie voor de Volksgezondheid van de Tweede Kamer inzake tabaksontmoedigingsbeleid. Dutch Tobacco Industry Collection, Bates No. JB2777. Retrieved from https://industrydocuments.library.ucsf.edu/ tobacco/docs/lxfp0219

Ministerie van Economische Zaken. (2010). Dossier voor kennismakingsgesprek met tabaksindustrie. Dutch Tobacco Industry Collection, Ministerie van Economische Zaken, Bates No. JB0533. Retrieved from https://industrydocuments.library.ucsf.edu/tobacco/docs/lxxb0191

Nagelhout, G. E., \& Fong, G. T. (2011). Netherlands: Plan to cut all health education. Tobacco Control, 20(4), 253-254.

National Clearinghouse for Smoking and Health. (1969). Smoking and health programs in other countries. Philip Morris Records, Bates No. 20160033192016003331. Retrieved from http://legacy.library.ucsf.edu/tid/jdh68e00

Nederlands Economisch Instituut. (1991). De evaluatie van het tabaksontmoedigingsbeleid nader beschouwd. Rotterdam: NEI.

Niemantsverdriet, T. (2011, November 9). Minister Edith Schippers: De vrouw van 75 miljard. Vrij Nederland. Retrieved from http://www.vn.nl/Archief/Politiek/ Artikel-Politiek/Minister-Edith-Schippers-De-vrouw-van-75-miljard.htm

NKI-AVL. (2012). Artsen zeggen NEE tegen tabak: Wij vragen de politiek om een effectief tabaksontmoedigingsbeleid. Amsterdam: NKI-AVL.

Pauw, P. M. (1971). Televisiereclame en anti-reclame. Dutch Tobacco Industry Collection, Bates No. 2501265710-2501265713. Retrieved from http://legacy.library.ucsf.edu/tid/pwr22e00

Philip Morris. (1996). Corporate Affairs 1996/1997 The Netherlands. Philip Morris Records, Bates No. 2501076006-2501076023. Retrieved from https:// www.industrydocumentslibrary.ucsf.edu/tobacco/docs/nzjl0112

Roscam Abbing, E. W. (1998). Tabaksontmoedigingsbeleid: Gezondheidseffectrapportage. Utrecht: Netherlands School of Public Health (NSPH).

Royal College of Physicians. (1962a). Smoking and health. London: Royal College of Physicians of London.

Royal College of Physicians. (1962b). Roken en gezondheid. Een rapport van de Koninklijk Genootschap van Londense artsen over roken in verband met longkanker en andere aandoeningen. Amsterdam: Strengholt. 
Royal College of Physicians. (1971). Smoking and health now. A new report and summary on smoking and its effects on health. Annals of Internal Medicine, 75(1), 147-148. https://doi.org/10.7326/0003-4819-75-1-147

Spijkerman, R., \& van den Ameele, A. N. (2001). Roken op het werk 2000 (een herhalingsonderzoek). Den Haag: Arbeidsinspectie.

Stichting van de Arbeid. (1992). Aanbeveling over de bescherming van de nietroker op het werk. Dutch Tobacco Industry Collection, Bates No. JB2035. Retrieved from https://www.industrydocumentslibrary.ucsf.edu/tobacco/ docs/khdp0219

STIVORO. (1999). 25 jaar STIVORO: een goed begin [year report]. Den Haag: STIVORO.

STIVORO. (2005). Nationaal Programma Tabaksontmoediging 2006-2010. Den Haag: STIVORO.

Studlar, D. T., \& Cairney, P. (2014). Conceptualizing punctuated and nonpunctuated policy change: Tobacco control in comparative perspective. International Review of Administrative Sciences, 80(3), 513-531. https://doi. org/10.1177/0020852313517997

Tobacco Manufacturers' Assocation. (1971). Gentlemen's agreement. Philip Morris Collection, Bates No. 2501265714-2501265715. Retrieved from http://legacy.library.ucsf.edu/tid/qwr22e00

U.S. Department of Health, Education, and Welfare. (1964). Smoking and health: Report of the Advisory Committee to the Surgeon General of the Public Health Service (Vol. DHEW publication no. (PHS) 64-1103). Washington, DC: Public Health Service.

Unknown (Philip Morris). (1979). Smoking o health-Five year plan, Bates No 2501020542-2501020686. Truth Tobacco Industry Documents.

US Public Health Service. (1970). Smoking and health programs around the world. American Tobacco Records, Bates No. 968012023-968012038. Retrieved from http://legacy.library.ucsf.edu/tid/cob34f00

Van den Putte, S. J. H. M., Yzer, M. C., Ten Berg, B. M., \& Steeveld, R. M. A. (2005). Nederland start met stoppen/Nederland gaat door met stoppen. Evaluatie van de STIVORO campagnes rondom de jaarwisseling 2003-2004. Amsterdam: Universiteit van Amsterdam, ASCOR.

Van Gennip, E. M. S. J. (2007). Brief STIVORO aan Ministerie van Algemene Zaken over beleidsvoornemen om de horeca-rookvrij te maken. Dutch Tobacco Industry Collection, Bates No. JB0344. Retrieved from https://www.industrydocumentslibrary.ucsf.edu/tobacco/docs/snhb0191

Van Leeuwen, M. J., \& Sleur, D. G. (1998). De economische effecten van maatregelen ter bestrijding van het roken. In E. Roscam Abbing (Ed.), Tabaksontmoedigingsbeleid: Gezondheidseffectrapportage. Utrecht: Netherlands School of Public Health (NSPH).

Van Rijn, M. (2014). Onderzoeken naar effecten verkooppunten en leeftijdverificatiesystemen tabaksproducten. Kamerbrief 626288-122861-VGP. 
Van Vliet, G. F. W. (1971). Gentlemen's agreement manufacturers on publicity vs. smoking and health. Philip Morris Collection, Bates No. 2501265716. Retrieved from http://legacy.library.ucsf.edu/tid/rwr22e00

Verdonk-Kleinjan, W. M. (2014). Impact assessment of the tobacco legislation: Effects of the workplace smoking ban and the tobacco sales ba to minors. PhD, Maastricht University, Maastricht.

Vijgen, S. M. C., Gelder, B. M. v., Baal, P. H. M. v., Zutphen, M. v., Hoogenveen, R. T., \& Feenstra, T. L. (2007). Kosten en effecten van tabaksontmoediging. Bilthoven: RIVM.

Visser, W. M. G. (2008). Accijnzen : Een onderzoek naar de rechtsgronden van de Nederlandse accijnzen aan de hand van 200 jaar parlementaire geschiedenis (1805-2007) en naar de werking van bet Europese accijnsregime binnen de interne markt in het licht van deze rechtsgronden. PhD, University of Amsterdam, Amsterdam. Retrieved from http://dare.uva.nl/document/98972

VWA. (2005). Evaluatie van de handhavingervaring van de Tabakswet 2002-2004: Een kwantitatieve en kwalitatieve analyse. Utrecht: NVWA.

VWS. (1991). Zelfregulering tabaksreclame voldoet niet. Press release 15 Oktober 1991, no 68 .

VWS. (2001). Tabaksnota "Samen naar een rookvrije samenleving" Truth Tobacco Industry Documents, Bates No. JB2316. Retrieved from https://industrydocuments.library.ucsf.edu/tobacco/docs/rfgp0219

VWS. (2003). Langer Gezond Leven: Ook een kwestie van gezond gedrag. Den Haag: Ministerie van VWS.

VWS. (2005). Evaluatie Tabaksontmoediging. Den Haag: Ministerie van VWS.

VWS. (2006). Nationaal Programma Tabaksontmoediging. Den Haag: Ministerie van VWS.

VWS. (2007). Gezond zijn, gezond blijven. Een visie op gezondheid en preventie. Den Haag: Ministerie van VWS.

VWS. (2011). Gezondheid dichtbij. Landelijke nota gezondheidsbeleid. Den Haag: Ministerie van VWS.

Wassink, W. F. (1948). Ontstaansvoorwaarden voor longkanker. Nederlands Tijdschrift voor Geneeskunde, 92, 3732-3747.

Wester, J. (1957). Roken en gezondheid. Rapport van de Gezondheidsraad. Nederlands Tijdschrift voor Geneeskunde, 107, 459-464.

WHO. (1975). Smoking and its effects on health. Report of a WHO expert committee No. 568, Technical Report Series. Geneva: World Health Organization.

WHO. (2003). WHO framework convention on tobacco control. Geneva: World Health Organization.

WHO. (2006). Legislating for smoke-free workplaces. Copenhagen: WHO Regional Office for Europe.

Willemsen, M. C. (2006). Rokers onder vuur? Invloed van de gewijzigde Tabakswet op rokers, met speciale aandacht voor verschillen tussen sociaal-economische klassen. Den Haag: STIVORO. 
World Bank. (1999). Curbing the epidemic: Governments and the economics of tobacco control. Washington: The World Bank.

WVC. (1991). Scherpere aanpak van tabaksontmoedigingsbeleid. Press release 16 Oktober 1991, no 69.

Wynder, W. L., \& Graham, E. A. (1950). Tobacco smoking as a possible etiological factor in bronchiogenic carcinoma: A study of six hundred and eighty-four proved cases. Journal of the American Medical Association, 143, 329-336.

Zeeman, G., \& De Beer, M.A. M. (2012). 50 jaar GVO en Gezondheidsbevordering: Geschiedenis van de tabaksontmoediging in Nederland; succesverhaal met een droevig einde. Tijdschrift voor Gezondheidswetenschappen, 90, 253-261.

Open Access This chapter is licensed under the terms of the Creative Commons Attribution 4.0 International License (http://creativecommons.org/licenses/ by $/ 4.0 /$ ), which permits use, sharing, adaptation, distribution and reproduction in any medium or format, as long as you give appropriate credit to the original author(s) and the source, provide a link to the Creative Commons license and indicate if changes were made.

The images or other third party material in this chapter are included in the chapter's Creative Commons license, unless indicated otherwise in a credit line to the material. If material is not included in the chapter's Creative Commons license and your intended use is not permitted by statutory regulation or exceeds the permitted use, you will need to obtain permission directly from the copyright holder.

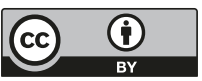

